\title{
Occupational exposure of firefighters to polycyclic aromatic hydrocarbons in non-fire work environments
}

\author{
Marta Oliveira ${ }^{\text {a,b }}$, Klara Slezakova ${ }^{\text {a,b }}$, Adília Fernandes ${ }^{\text {c }}$, João Paulo Teixeira ${ }^{\text {d,e }}$, Cristina Delerue-Matos ${ }^{\text {a }}$, \\ Maria do Carmo Pereira ${ }^{\mathrm{b}}$, Simone Morais ${ }^{\mathrm{a}, *}$ \\ a REQUIMTE-LAQV, Instituto Superior de Engenharia do Porto, Instituto Politécnico do Porto, R. Dr. António Bernardino de Almeida 431, 4200-072 Porto, Portugal \\ ${ }^{b}$ LEPABE, Departamento de Engenharia Química, Faculdade de Engenharia, Universidade do Porto, R. Dr. Roberto Frias, $4200-465$ Porto, Portugal \\ c Escola Superior de Saúde, Instituto Politécnico de Bragança, Avenida D. Afonso V, 5300-121, Bragança, Portugal \\ d Instituto Nacional de Saúde Pública, Departamento de Saúde Ambiental, Rua Alexandre Herculano 321, 4000-055 Porto, Portugal \\ e Universidade do Porto, Instituto de Saúde Pública, Rua das Taipas 135, 4050-600 Porto, Portugal
}

\section{H I G H L I G H T S}

- Firefighters' air exposures to PAHs in non-fire work settings were assessed.

- Obtained PAH levels fulfilled occupational limits and air quality guidelines.

- Congeners with 2-3 rings were the predominant contributors to total PAHs levels.

- Exposure sources were mixed ones (both pyrogenic and petrogenic origin)

- Incremental lifetime cancer risks exceeded WHO-based guideline at all fire houses.

\section{A R T I C L E I N F O}

\section{Article history:}

Received 27 October 2016

Received in revised form 7 March 2017

Accepted 8 March 2017

Available online 17 March 2017

Editor: D. Barcelo

\section{Keywords:}

Occupational exposure

Firefighters

Polycyclic aromatic hydrocarbons (PAHs)

Risk

Indoor air

Legislative limits

\section{G R A P H I C A L A B S T RACT}

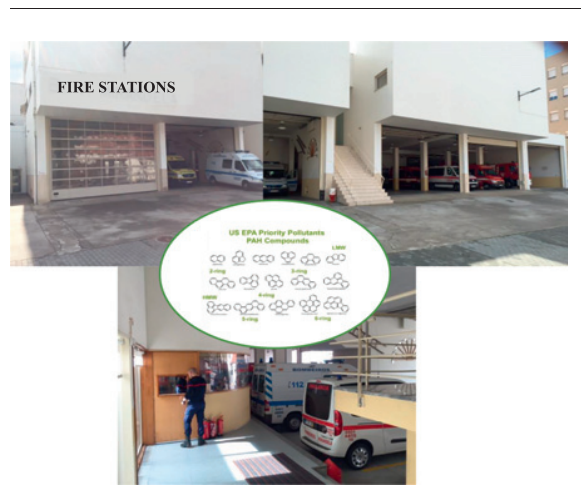

\begin{abstract}
A B S T R A C T
This work aims to characterize personal exposure of firefighters to polycyclic aromatic hydrocarbons (PAHs) in non-fire work environments (fire stations), and assesses the respective risks. Eighteen PAHs (16 considered by USEPA as priority pollutants, dibenzo[a,l]pyrene and benzo[j]fluoranthene) were monitored in breathing zones of workers at five Portuguese fire stations during a normal shift. The obtained levels of PAHs fulfilled all existent occupational exposure limits as well as air quality guidelines with total concentrations ( $\mathrm{PAH}$ ) in range of $46.8-155 \mathrm{ng} \mathrm{m}^{-3}$. Light compounds (2-3 rings) were the most predominant congeners (74-96\% of $\Sigma \mathrm{PAHs}$ ) whereas PAHs with 5-6 rings accounted 3-9\% of $\Sigma$ PAHs. Fuel and biomass combustions, vehicular traffic emissions, and use of lubricant oils were identified as the main sources of PAHs exposure at the studied fire corporations. Incremental lifetime cancer risks were below the recommend USEPA guideline of $10^{-6}$ and thus negligible for all the studied subjects, but WHO health-based guideline level of $10^{-5}$ was exceeded (9-44 times) at all fire corporations. These results thus show that even during non-fire situations firefighters are exposed to PAHs at levels that may promote some adverse health outcomes; therefore the respective occupational exposures to these compounds should be carefully controlled.
\end{abstract}

\footnotetext{
* Corresponding author.

E-mail address: sbm@isep.ipp.pt (S. Morais).
} 


\section{Introduction}

Firefighters (IARC, 2010a) represent one of the most hazardous occupation (Baxter et al., 2014). During their professional conduct, firefighters are exposed to a complex mixture of pollutants including particles (fine and respirable particulate matter) and a wide range of gaseous chemicals (such as carbon monoxide and dioxide, nitrogen oxides, carbonyls, volatile and semi-volatile organic compounds; Estrellan and Lino, 2010; Lemieux et al., 2004; Lewtas, 2007; Miranda et al., 2010; Reisen et al., 2006). Among them polycyclic aromatic hydrocarbons (PAHs) are especially relevant due to their mutagenic and genotoxic properties (Annesi-Maesano et al., 2007; IARC, 2002, 2010a, 2010b; Tuntawiroon et al., 2007), some of them being considered as endocrine disrupting chemicals (WHO, 2013). Occupational exposure to PAHs has been associated with increased risks of various cancers (lungs, bladder, skin, urinary and gastrointestinal systems; Boffetta et al., 1997; Diggs et al., 2011; Rota et al., 2014); cell damage via gene mutation (Kamal et al., 2015; Kuang et al., 2013; Poirier, 2004), oxidative stress and cardiovascular diseases (Burstyn et al., 2005; Jeng et al., 2011; Kim et al., 2013; Lee et al., 2011) and cardiovascular mortality (Brucker et al., 2014). Concerning potential exposure and adverse health effects, United States Environmental Protection Agency (USEPA) has identified 16 priority congeners (USEPA, 2014).

From chemical perspective, PAHs are compounds containing only hydrogen and carbon that are composed of multiple aromatic rings. They are abundant in soils and marine sediments, fresh water, and in atmosphere where the more health hazardous congeners (WHO, 2010) are predominantly bound to fine (i.e. $\mathrm{PM}_{2.5}$ ) particles (Castro et al., 2011; Slezakova et al., 2011, 2013b). Fire emissions and smoke are the most relevant sources of PAHs exposure for firemen (Booze et al., 2004; Fent et al., 2013, 2014; Kirk and Logan, 2015a), but the compounds are formed by other man-made sources such as industrial processes, incinerators, coal-fired boilers and power plants, and last but not least, by traffic emissions (Hanedar et al., 2014; Ravindra et al., 2008; Slezakova et al., 2013a, 2013b). In confined spaces, secondhand tobacco smoke, combustion emissions (from cooking stoves and fireplaces) and infiltration of ambient air emissions are responsible for the presence of PAHs (Chen et al., 2012; Qi et al., 2014; Shen et al., 2012; Slezakova et al., 2014). The toxicity of PAHs is largely attributed to their reactive oxygenated metabolites, potential of causing oxidative stress (Kamal et al., 2015) and the adducts of their metabolites with DNA (Rengarajan et al., 2015). The DNA-binding is considered to be essential for the carcinogenic effect (Pratt et al., 2011; Tarantini et al., 2011) with DNA adducts being identified in various human tissues (Ziech et al., 2011); cancer is the primarily risk for PAHs exposure (Boström et al., 2002; Kim et al., 2013) and in that view International Agency for Research on Cancer (IARC) has categorised benzo[a]pyrene (B[a]P; a marker of PAHs exposure) as known human carcinogen (Group 1) (IARC, 2010b) whereas other congeners are classified as probable and/or possible ones (Group 2A and 2B, respectively). Further scientific evidence has also linked exposure to PAHs with cardiovascular diseases (Lewtas, 2007; Korashy and El-Kadi, 2006). Adverse health outcomes (hemotoxicity and carcinogenicity; Fabian et al., 2014; Fent and Evans, 2011; Robinson et al., 2008) and also excess morbidity and mortality have been reported for firefighters' occupational exposure, with cardiovascular diseases being the primary cause for the deaths (in approximately $45 \%$ of firefighters) and a major cause of the increased morbidity (Gaughan et al., 2014a, 2014b; Soteriades et al., 2011); the additional exposure to PAHs may promote and/or worsen the existent cardiovascular diseases of firefighters (Lewtas, 2007). Because of the relevance of this topic, data regarding firefighters' exposure to PAHs have been emerging. The most extensive studies that assessed exposures in various combat situations and scenarios (i.e. training sessions, mainly prescribed burns management, suppression and overhaul of controlled structure burns) have been conducted in USA (Baxter et al., 2014; Bolstad-Johnson et al., 2000; Booze et al., 2004; Fent et al., 2013,
2014; Fent and Evans, 2011; Pleil et al., 2014; Robinson et al., 2008) and Australia (Kirk and Logan, 2015a). In addition, some authors reported that fire-generated contaminants were tracked back to fire stations through firefighters' protective gear (gloves, boots and turnout equipment) and vehicles (Alexander and Baxter, 2014; Fabian et al., 2014; Fent et al., 2013; Kirk and Logan, 2015a, 2015b; Laitinen et al., 2010; Shen et al., 2015) but only few studies investigated occupational exposure to PAHs at fire stations (being mainly conducted in USA). Due to the geographical differences such different materials and construction techniques used for building houses and structures, and due to differences in the firefighting practices (which can influence the smoke emissions and consequently the respective exposure; Reinhardt and Ottmar, 2004; Reisen and Brown, 2009; De Vos et al., 2009), these reported exposure data may be significantly different from those of European firefighters. Furthermore, the seasonal trends of PAHs (Liu et al., 2008; Melymuk et al., 2012; Ravindra et al., 2006) may lead to further differences. This study aimed to investigate firefighters' exposure to PAHs in work (non-fire incident) settings. The levels of 16 PAHs considered by USEPA as priority pollutants, dibenzo[a,l]pyrene $(\mathrm{D}[a, l] \mathrm{P})$ and benzo[j]fluoranthene $(\mathrm{B}[j] \mathrm{F}$; a monitoring is suggested by Directive 2004/107/EC, 2005) were measured in the breathing air zone of firefighters in five Portuguese municipalities. The potential emission sources in the work settings were identified by diagnostic ratios and the occupational risks due to PAHs exposure in the respective environments were assessed.

\section{Material and methods}

\subsection{Sample collection}

Portugal belongs to the five Southern European Member States which every year suffer the most forest fires (Joint Research Centre, 2011). Typically, central and northern region of the country are affected the most by forest fires; in 2014 these two regions exhibited a burnt area of 14,938 ha $(\sim 75 \%$ of the total) with northern region also registering the prevailing number of fire occurrences ( $40 \%$ of the total number of fires) (Joint Research Centre, 2015). The sample collection was thus conducted in northern region in Braganza district (Fig. 1) where annual average air temperature was $12.7^{\circ} \mathrm{C}$ and precipitation was $900.2 \mathrm{~mm}$ (INE, 2015); summer was hot and dry (average temperature of $28.2^{\circ} \mathrm{C}$, precipitation: $3.6 \mathrm{~mm}$ ).

The personal sampling was conducted during a period of 28 days (May-June 2014) in subjects (Table 1) who worked as professional firefighters at corporations of five different municipalities: Vimioso (VMS), Macedo de Cavaleiros (MCC), Izeda (IZD), Vila Flor (VFR), and Alfândega da Fé (AFF). All fire corporations were located in central zones of rather small towns with relatively low populations (between 1212 and 15,776 at IZD and MCC; Table 1) and were considered as urban background sites. Each fire station was composed of track/car garages that were in general indirectly connected with working areas, control room and offices, as well as with an area of living quarters (Figs. 1S and $2 \mathrm{~S}$ ). For each subject, additional information (age, weight, gender, education, duration of employment; Table 1) was collected by means of structured questionnaire (WHO, 2016). All participating firemen were non-smokers. Information on further PAH exposures such as transportation to work, smoking and diet habits were also registered (Table 1) with participants reporting the most frequently consumed meals as: boiled $>$ roasted $>$ grilled.

The study included $18 \mathrm{PM}_{2.5}$-bound PAHs, namely naphthalene (Nap), acenaphthylene (Acy), acenaphthene (Ace), fluorene (Flu), phenanthrene (Phe), anthracene (Ant), fluoranthene (Fln), pyrene (Pyr), benz $[a]$ anthracene $(\mathrm{B}[\mathrm{a}] \mathrm{A})$, chrysene (Chry), benzo[b $+\mathrm{j}]$ fluoranthene $(\mathrm{B}[\mathrm{b}+\mathrm{j}] \mathrm{F})$, benzo[ $k]$ fluoranthene $(\mathrm{B}[k] \mathrm{F})$, benzo[a]pyrene $(\mathrm{B}[a] \mathrm{P})$, dibenz $[a, h]$ anthracene $(\mathrm{D}[a, h] \mathrm{A})$, benzo[ghi]perylene $(\mathrm{B}[$ ghi $] \mathrm{P})$, indeno[1,2,3-cd]pyrene (InP), and dibenzo[a,l]pyrene $(\mathrm{D}[a, l] \mathrm{P})$. Sampling was conducted in breathing zones of the selected 


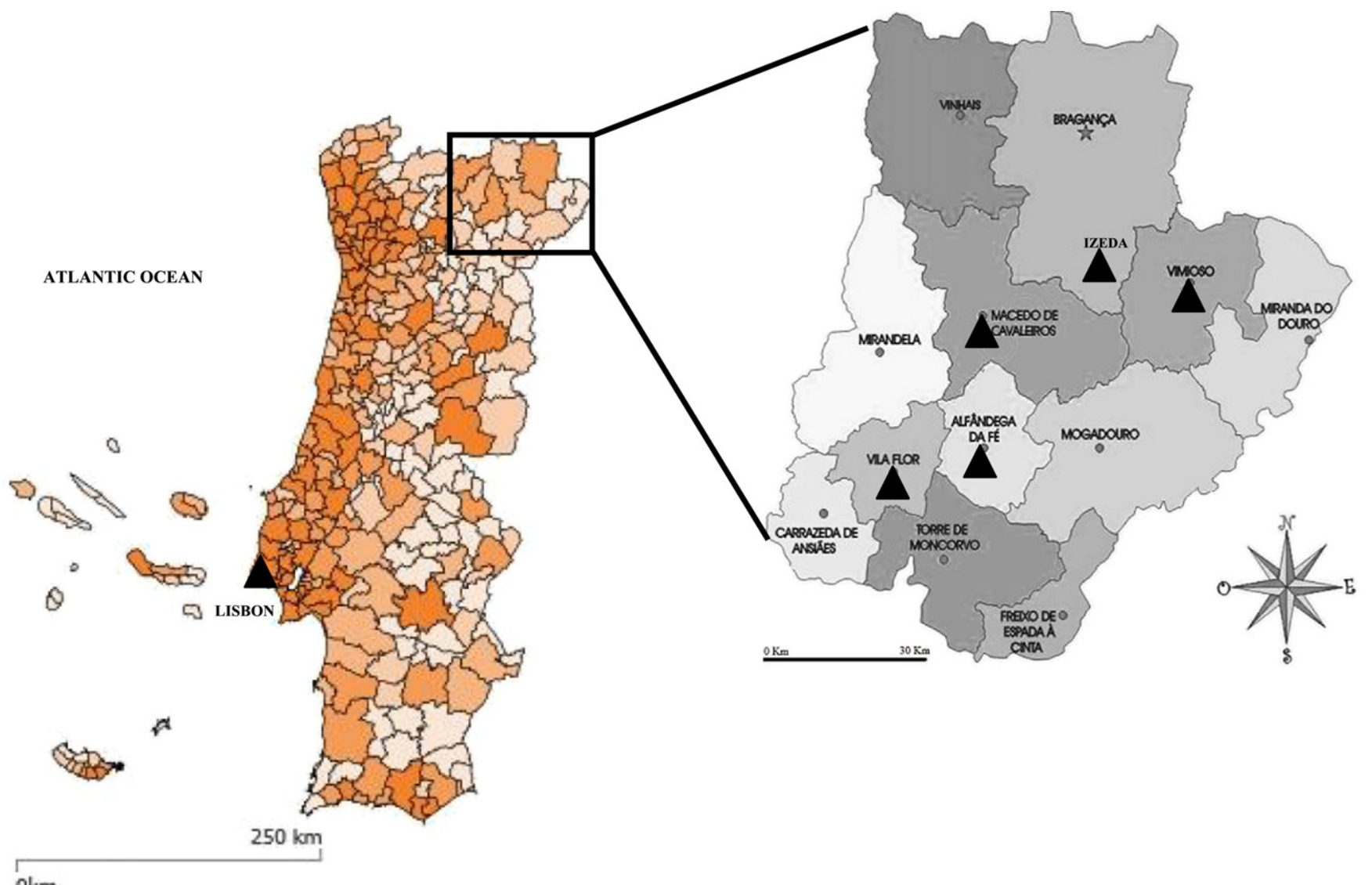

Fig. 1. Geographical representation of the study area.

subjects during a continuous 4-h period of a regular shift of a single day. The personal sampling ( $n=54$ ) was done according to USEPA IP-10A method (USEPA, 1990) using a personal environmental monitor (PEM ${ }^{\mathrm{TM}}$; SKC Ltd., United Kingdom), i.e. single stage impactor $\left(\mathrm{PM}_{2.5}\right)$ that was placed in breading zone (at height $152-178 \mathrm{~cm}$ ) of each subject combined with personal air sampling pump (Gilian, model GilAir3; Sensidyne, USA; air flow rate $2 \mathrm{~L} \mathrm{~min}^{-1}$ ) mounted at the waist (total volume of sampled air was $480 \mathrm{~L}$ per sample) All subjects moved freely according their needs within the stations and performed regular working tasks as usually. Polytetrafluoroethylene membrane disks ( $2 \mu \mathrm{m}$ porosity, Ø37 mm; SKC Ltd., UK) were used for the collection of $\mathrm{PM}_{2.5}$. After the sampling, filters were placed in polyethylene containers and stored (at $-20^{\circ} \mathrm{C}$ ) for the chemical analysis.

All firehouses were ventilated by opening windows (when needed); air conditionings systems were not available. Smoking was prohibited in all areas of fire stations (indoor places, garages/ truck bays). During the sampling a record of potential emission sources (vehicles arrivals and/or departures, vehicles and/or equipment maintenances, use of cooking appliances, etc.), and the general activities of the study subjects were recorded (Table 1S of the Supplementary Material).

\subsection{PAHs quantification}

PAHs were determined according to Castro et al. $(2009,2011)$ that in details describe all steps of the validation of the used analytical method, which consisted of extraction (microwave assisted) and quantification by liquid chromatography with fluorescence ( 17 compounds) and photodiode array (acenaphthylene) detection. For readers convenience, the information on the analytical procedure and quality control is also presented in Supplementary Material (Section 1S and Table 2S).

\subsection{Risk assessment}

The toxicity equivalent concentrations $\left(\mathrm{B}[\mathrm{a}] \mathrm{P}_{\mathrm{eq}}\right)$ based on the toxicity of $\mathrm{B}[a] \mathrm{P}$ were calculated. Toxicity equivalency factors (TEF) proposed by Nisbet and LaGoy (Boström et al., 2002) were used. The excess lifetime risk of lung cancer due to PAH exposure was then estimated by quantitative risk assessment methodology (WHO, 1987, 2000) using unit risk of $8.7 \times 10^{-5}$ (i.e. 8.7 cases per 100,000 people with chronic inhalational exposure to $1 \mathrm{ng} \mathrm{m}^{-3}$ of $\mathrm{B}[\mathrm{a}] \mathrm{P}$ over a lifetime of 70 years) and considering $8 \mathrm{~h}$ period for a work shift.

The incremental lifetime cancer risks (ILR) from inhalation exposure to particulate PAHs were estimated according to the USEPA methodology (Region III Risk-based Concentration Table; USEPA, 2016); ILR below $10^{-6}$ are denoted as safe ones, whereas potentially high risks are estimated by values $>10^{-4}$ (USEPA, 1989). The full details of the methodology and the ILR calculations can be found in Oliveira et al. (2016a). The concentrations of PAHs (determined for each subject by personal air sampling) were used and the exposure durations (i.e. years of employment as firefighters), which were obtained for each subject. For reader's convenience, Table 3S demonstrates an example of ILR calculations; default parameters are summarized in Tables $4 \mathrm{~S}$ and $5 \mathrm{~S}$.

\subsection{Statistical analysis}

Statistical analyses were done in SPSS (IBM SPSS Statistics 20), Statistica software (v. 7, StatSoft Inc., USA) and Excel (v. 16.0, Microsoft Corporation, USA). Nonparametric Mann-Whitney $U$ test was used to compare the mean values once normal distribution was not observed by Shapiro-Wilk's test. Statistical significance was defined as $p<0.05$. 
Table 1

Characterization of fire stations and the study population $(n=54)$ : Vimioso (VMS), Macedo de Cavaleiros (MCC), Izeda (IZD), Vila Flor (VFR) and Alfândega da Fé (AFF).

\begin{tabular}{|c|c|c|c|c|c|}
\hline & \multicolumn{5}{|l|}{ Fire station } \\
\hline & VMS & MCC & IZD & VFR & AFF \\
\hline Site characterization & Urban background & Urban background & Urban background & Urban background & Urban background \\
\hline Location & Town & Town & Town & Town & Town \\
\hline Number of inhabitants & 4669 & 15,776 & 1212 & 6697 & 5104 \\
\hline Year of construction & 1978 & 2012 & 2005 & 1979 & 1991 \\
\hline Year of refurbishment & 1995 & - & - & 2008 & - \\
\hline Sampling date & 28.5.2014 & 2.6 .2014 & 16.6 .2014 & 24.6.2014 & 17.6.2014 \\
\hline \multicolumn{6}{|l|}{ Meteorological conditions:_ } \\
\hline Air temperature $\left({ }^{\circ} \mathrm{C}\right)$ & $19.4(10.3-26.3)$ & $18.6(8.2-25.5)$ & $19.0(10.8-25.7)$ & $16.3(12.8-20.0)$ & $19.5(9.1-27.4)$ \\
\hline Relative humidity (\%) & $57.4(33.7-86.0)$ & $55.1(36.6-87.7)$ & $46.5(27.4-73.6)$ & $80.1(64.5-90.5)$ & $46.1(27.4-74.0)$ \\
\hline Wind speed $\left(\mathrm{m} \mathrm{s}^{-1}\right)$ & $2.1(0.1-6.7)$ & $1.3(0.1-4.0)$ & $3.0(0.9-5.6)$ & $0.9(0.0-3.4)$ & $2.0(0.2-4.4)$ \\
\hline Wind direction & S-SW & SW-S & NE-E & S-SW & E-SE \\
\hline Solar radiation $\left(\mathrm{kW} \mathrm{m}^{-2}\right)$ & $0.1(0.0-0.5)$ & $0.2(0.0-0.5)$ & $0.2(0.0-0.5)$ & $0.1(0.0-0.5)$ & $0.2(0.0-0.5)$ \\
\hline Precipitation (mm) & 0.0 & 0.0 & 0.0 & $0.1(0.0-1.6)$ & 0.0 \\
\hline $\begin{array}{l}\text { Potential outdoor emission } \\
\text { sources }\end{array}$ & $\begin{array}{l}\text { Equipped with } \\
\text { gasoline station }\end{array}$ & $\begin{array}{l}\text { Gasoline station } \\
\text { approximately } 500 \mathrm{~m}\end{array}$ & $\begin{array}{l}\text { Gasoline station } \\
\text { approximately } 1 \mathrm{~km}\end{array}$ & $\begin{array}{l}\text { Gasoline station } \\
\text { approximately } 500 \mathrm{~m}\end{array}$ & $\begin{array}{l}\text { Gasoline stations } \\
\text { approximately } 500 \mathrm{~m}\end{array}$ \\
\hline \multicolumn{6}{|l|}{ Vehicles: } \\
\hline Departures & 4 & 5 & 3 & 3 & 3 \\
\hline Arrivals & 4 & 4 & 4 & 4 & 3 \\
\hline $\begin{array}{l}\text { Number of workers (firefighters) } \\
\text { at fire station }\end{array}$ & 70 & 50 & 38 & 40 & 45 \\
\hline Floor coating (control center) & Polyvinyl chloride & Wood & Ceramic tiles & Ceramic tiles & Ceramic tiles \\
\hline Number of windows and doors & 2 windows; & 1 window; & 3 windows: & 3 windows ( 1 opened); & 1 window; \\
\hline (control center) & 2 doors & 1 door & 1 door & 1 door & 1 door \\
\hline \multicolumn{6}{|l|}{ Ventilation at control center: } \\
\hline Beginning of day & Yes & Yes & Yes & Yes & Yes \\
\hline During the day & Yes & Yes & Yes & Yes & Yes \\
\hline End of the day & No & No & No & No & No \\
\hline During cleaning & Yes & Yes & Yes & Yes & Yes \\
\hline Cleaning & 1 per day & 1 per day & 1 per day & 1 per day & 1 per day \\
\hline Study population (\%) & 22 & 22 & 22 & 22 & 12 \\
\hline \multirow[t]{2}{*}{ Gender (\%) } & Male: 75 & Male: 75 & Male: 50 & Male: 100 & Male: 100 \\
\hline & Female: 25 & Female: 25 & Female: 50 & & \\
\hline Age (years) & $36(26-43)$ & $22(19-24)$ & $33(12-35)$ & $23(18-25)$ & $35(30-40)$ \\
\hline Weight $(\mathrm{kg})$ & $74(61-88)$ & $68(63-72)$ & $76(62-90)$ & $93(78-101)$ & $87(73-100)$ \\
\hline Employment duration (years) & $18(3-25)$ & $4(2-7)$ & $11(4-17)$ & $5(2-10)$ & $15(12-18)$ \\
\hline \multirow[t]{3}{*}{ Education } & Secondary: $75 \%$ & Secondary: $50 \%$ & Secondary: $100 \%$ & Elementary: $25 \%$ & Elementary $50 \%$ \\
\hline & Higher: $25 \%$ & Higher: 50\% & & Secondary: $50 \%$ & Secondary: $50 \%$ \\
\hline & & & & Higher: $25 \%$ & \\
\hline Smoking (yes/no) & No & No & No & No & No \\
\hline Allergy & Sea food, 1 subject & No & Pollens; 1 subject & No & Pollens; 1 subject \\
\hline Medication & Yes, 1 subject & No & None & No & Yes, 1 subject \\
\hline
\end{tabular}

\section{Results and discussion}

\subsection{PAH levels}

The levels of PAHs determined in the breathing air zones of studied subjects working at five fire corporations are summarized in Table 2. The total levels of PAHs ( $\Sigma$ PAHs) in the breathing zones of workers varied between the five corporations. As shown, the lowest levels (i.e. median $\Sigma$ PAHs) were found at VFR $\left(46.8 \mathrm{ng} \mathrm{m}^{-3}\right)$ being significantly $(p<0.001)$ different than at other corporations (except for AFF; $p=$ 0.169) whereas VMS exhibited the highest concentrations (154 $\mathrm{ng} \mathrm{m}^{-3}$ ), approximately 3 times higher than at VFR. VMS corporation had the highest occupancy rate (more $30-45 \%$ of workers than at the remaining firehouses) and was the only one equipped with a gasoline station which could have caused the elevated PAH levels. For the other fire stations, similar levels of $\Sigma$ PAHs were found at MCC $\approx$ IZD (104-107 $\mathrm{ng} \mathrm{m}^{-3}$ ) being higher than those at AFF $\left(77.3 \mathrm{ng} \mathrm{m}^{-3}\right)$. It is noteworthy that, though MCC and IZD fire stations were situated in cities with different populations (15,776 and 1212 inhabitants, respectively for MCC and IZD), the overall $\Sigma$ PAHs were rather similar $(p=0.102)$; both firehouses were the most recently constructed ones (2005-2012 as opposed to 1978-1979 (for VMS and VFR, respectively) and 1991 (for AFF)). The building characteristics as well as other factors such as the presence of emission sources and performed activities of occupants, type of microenvironments (physical characteristics of the indoor/outdoor places, occupancy, ventilation rates, etc.), and overall pollution levels (including seasonal, meteorological and geographical differences) influence the personal exposure to a pollutant (Chen et al., 2012; IARC, 2010a, 2010b; Madureira et al., 2016; Oliveira et al., 2015a).

The results in Table 2 also show that contribution profiles of PAHs at all stations were somewhat similar. Acy was the predominant PAH at all stations (except for MCC where it was the 2nd most abundant one) accounting between $44 \%$ (at VMS) and $69 \%$ (AFF) of the total PAH content (i.e. $\mathrm{PAAHs}$ ). This PAH is a component of organic material such as coal tar and crude oil. The presence of Acy in air may result from evaporation from these organic materials but it may also be released into the environment during fires (Kirk and Logan, 2015a, 2015b); wood combustion results in emissions of smoke with predominant abundance of this PAH (Perwak et al., 1982). Nap was the $2^{\text {nd }}$ most abundant PAH at stations IZD, VFR and AFF, accounting for $12-16 \%$ of $\Sigma$ PAHs with levels much lower than those reported for fire stations in Cincinnati, USA (9.22 $\mu \mathrm{g} \mathrm{m}^{-3}$ at kitchen area up to $9.24 \mu \mathrm{g} \mathrm{m}^{-3}$ at truck bay; Baxter et al., 2014). Although no specific sources of Acy and Nap were identified, higher abundance of Acy could be due secondary transfer (via contaminated protective material) whereas in indoor air Nap emissions may result from incomplete combustion (wood, tobacco) and from evaporation of Nap-containing materials (such moth repellents air fresheners, crude oil, petroleum products) (Jia and Batterman, 2010). It is necessary to remark that Nap is recognized as relevant indoor pollutant by WHO that recommended an annual guideline value in indoor air of $10 \mu \mathrm{g} \mathrm{m}^{-3}$ (WHO, 2010). Whereas the levels reported Baxter et al. (2014) are close to that value, the concentrations in the breathing zones 
Table 2

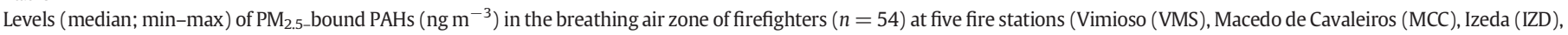
Vila Flor (VFR), Alfândega da Fé (AFF)).

\begin{tabular}{|c|c|c|c|c|c|}
\hline Compound* & $\begin{array}{l}\text { Fire station } \\
n=12 \\
\text { VMS }\end{array}$ & $\begin{array}{l}n=12 \\
\mathrm{MCC}\end{array}$ & $\begin{array}{l}n=12 \\
\text { IZD }\end{array}$ & $\begin{array}{l}n=12 \\
\text { VFR }\end{array}$ & $\begin{array}{l}n=6 \\
\text { AFF }\end{array}$ \\
\hline Naphthalene & $\begin{array}{l}9.78 \\
(8.98-10.1)\end{array}$ & $\begin{array}{l}11.0 \\
(2.09-14.0)\end{array}$ & $\begin{array}{l}16.3 \\
(12.1-22.2)\end{array}$ & $\begin{array}{l}5.54 \\
(4.59-14.5)\end{array}$ & $\begin{array}{l}8.98 \\
(7.16-9.80)\end{array}$ \\
\hline Acenaphthylene & $\begin{array}{l}68.7 \\
(42.7-125.4)\end{array}$ & $\begin{array}{l}24.0^{\#} \\
(24.0-95.4)\end{array}$ & $\begin{array}{l}37.3 \\
(24.0-52.6)\end{array}$ & $24.0^{+}(24.0-24.0)$ & $\begin{array}{l}53.0 \\
(24.0-101)\end{array}$ \\
\hline Acenaphthene & $\begin{array}{l}65.8 \\
(1.62-75.6)\end{array}$ & $\begin{array}{l}58.2 \\
(28.7-94.1)\end{array}$ & $\begin{array}{l}25.0 \\
(22.9-25.5)\end{array}$ & $\begin{array}{l}1.62^{\alpha} \\
(1.62-8.85)\end{array}$ & $\begin{array}{l}1.62^{\alpha} \\
(1.62-8.94)\end{array}$ \\
\hline Fluorene & $\begin{array}{l}0.405 \\
(0.272-0.460)\end{array}$ & $\begin{array}{l}0.665 \\
(0.272-6.01)\end{array}$ & $\begin{array}{l}1.36 \\
(0.993-1.57)\end{array}$ & $\begin{array}{l}0.272 \\
(0.272-0.491\end{array}$ & $\begin{array}{l}0.697 \\
(0.422-0.823)\end{array}$ \\
\hline Phenanthrene & $\begin{array}{l}3.54 \\
(3.26-3.89)\end{array}$ & $\begin{array}{l}4.51 \\
(3.45-17.8)\end{array}$ & $\begin{array}{l}9.55 \\
(8.14-11.1)\end{array}$ & $\begin{array}{l}3.14 \\
(2.72-3.85)\end{array}$ & $\begin{array}{l}4.35 \\
(4.21-9.05)\end{array}$ \\
\hline Anthracene & $\begin{array}{l}0.223^{+} \\
(0.223-0.223)\end{array}$ & $\begin{array}{l}0.223^{\alpha} \\
(0.223-0.551)\end{array}$ & $\begin{array}{l}0.330 \\
(0.317-0.367)\end{array}$ & $\begin{array}{l}0.223^{+} \\
(0.223-0.223)\end{array}$ & $\begin{array}{l}0.223^{+} \\
(0.233-0.233)\end{array}$ \\
\hline Fluoranthene & $\begin{array}{l}0.351^{+} \\
(0.351-0.351)\end{array}$ & $\begin{array}{l}0.351^{\alpha} \\
(0.351-0.811)\end{array}$ & $\begin{array}{l}1.82 \\
(1.12-2.94)\end{array}$ & $\begin{array}{l}0.716^{\alpha} \\
(0.351-1.28)\end{array}$ & $\begin{array}{l}0.596^{\#} \\
(0.351-0.867)\end{array}$ \\
\hline Pyrene & $\begin{array}{l}0.292^{\alpha} \\
(0.292-0.653)\end{array}$ & $\begin{array}{l}0.568^{\alpha} \\
(0.292-0.878)\end{array}$ & $\begin{array}{l}2.24 \\
(0.929-3.99)\end{array}$ & $\begin{array}{l}0.553^{\alpha} \\
(0.292-0.942)\end{array}$ & $\begin{array}{l}0.719 \\
(0.292-1.45)\end{array}$ \\
\hline Benz[a]anthracene & $\begin{array}{l}0.205^{\#} \\
(0.205-0.783)\end{array}$ & $\begin{array}{l}0.205^{\mathrm{e}} \\
(0.205-0.205)\end{array}$ & $\begin{array}{l}0.257^{\alpha} \\
(0.205-0.325)\end{array}$ & $\begin{array}{l}0.205^{\mathrm{e}} \\
(0.205-0.205)\end{array}$ & $\begin{array}{l}0.205^{\mathrm{e}} \\
(0.205-0.205)\end{array}$ \\
\hline Chrysene & $\begin{array}{l}0.145^{\mathrm{e}} \\
(0.145-0.145)\end{array}$ & $\begin{array}{l}0.145^{\&} \\
(0.145-0.271)\end{array}$ & $\begin{array}{l}0.937^{\alpha} \\
(0.145-1.80)\end{array}$ & $\begin{array}{l}0.561^{\&} \\
(0.145-0.803)\end{array}$ & $\begin{array}{l}0.390^{\alpha} \\
(0.145-0.784)\end{array}$ \\
\hline Benzo[b $+\mathrm{j}]$ fluoranthene & $\begin{array}{l}0.844^{+} \\
(0.844-0.844)\end{array}$ & $\begin{array}{l}0.844^{+} \\
(0.844-0.844)\end{array}$ & $\begin{array}{l}0.844 \\
(0.844-1.34)\end{array}$ & $\begin{array}{l}1.51 \\
(0.844-2.21)\end{array}$ & $\begin{array}{l}0.844^{+} \\
(0.844-0.844)\end{array}$ \\
\hline Benzo[ $k]$ fluoranthene & $\begin{array}{l}0.134^{+} \\
(0.134-0.134)\end{array}$ & $\begin{array}{l}0.134^{+} \\
(0.134-0.134)\end{array}$ & $\begin{array}{l}0.181 \\
(0.134-0.252)\end{array}$ & $\begin{array}{l}0.281 \\
(0.134-0.403)\end{array}$ & $\begin{array}{l}0.134^{+} \\
(0.134-0.134)\end{array}$ \\
\hline Benzo[a]pyrene & $\begin{array}{l}0.277^{+} \\
(0.277-0.277)\end{array}$ & $\begin{array}{l}0.277^{+} \\
(0.277-0.277)\end{array}$ & $\begin{array}{l}0.277^{+} \\
(0.277-0.277)\end{array}$ & $\begin{array}{l}0.977 \\
(0.277-1.16)\end{array}$ & $\begin{array}{l}0.449 \\
(0.277-0.570)\end{array}$ \\
\hline Dibenzo[a,l]pyrene & $\begin{array}{l}0.671^{+} \\
(0.671-0.671)\end{array}$ & $\begin{array}{l}0.671^{+} \\
(0.671-0.671)\end{array}$ & $\begin{array}{l}0.671^{+} \\
(0.671-0.671)\end{array}$ & $\begin{array}{l}0.671^{+} \\
(0.671-0.671)\end{array}$ & $\begin{array}{l}0.671^{+} \\
(0.671-0.671)\end{array}$ \\
\hline Dibenz $[a, h]$ anthracene & $\begin{array}{l}0.499^{+} \\
(0.499-0.499)\end{array}$ & $\begin{array}{l}0.499^{+} \\
(0.499-0.499)\end{array}$ & $\begin{array}{l}0.499^{+} \\
(0.499-0.499)\end{array}$ & $\begin{array}{l}2.79^{\alpha} \\
(0.499-3.43)\end{array}$ & $\begin{array}{l}1.11^{\&} \\
(0.499-2.10)\end{array}$ \\
\hline Benzo[ghi]perylene & $\begin{array}{l}2.50 \\
(0.355-3.04)\end{array}$ & $\begin{array}{l}4.16 \\
(0.355-4.74)\end{array}$ & $\begin{array}{l}6.23 \\
(5.28-7.55)\end{array}$ & $\begin{array}{l}3.52 \\
(3.10-4.42)\end{array}$ & $\begin{array}{l}3.13 \\
(2.80-3.39)\end{array}$ \\
\hline Indeno[1,2,3-cd]pyrene & $\begin{array}{l}0.185^{+} \\
(0.185-0.185)\end{array}$ & $\begin{array}{l}0.185^{+} \\
(0.185-0.185)\end{array}$ & $\begin{array}{l}0.185^{+} \\
(0.185-0.185)\end{array}$ & $\begin{array}{l}0.185^{+} \\
(0.185-0.185)\end{array}$ & $\begin{array}{l}0.185^{\&} \\
(0.185-0.626)\end{array}$ \\
\hline ¿PAHs & $\begin{array}{l}154^{\mathrm{ab}} \\
(67.4-218)\end{array}$ & $\begin{array}{l}107^{\mathrm{abc}} \\
(66.8-172)\end{array}$ & $\begin{array}{l}104^{\text {bce }} \\
(92.6-119)\end{array}$ & $\begin{array}{l}46.8^{\text {de }} \\
(40.1-54.9)\end{array}$ & $\begin{array}{l}77.3^{\text {cde }} \\
(47.4-130)\end{array}$ \\
\hline
\end{tabular}

Note: When a concentration of a compound was below the respective LOD, the value of LOD $/ \sqrt{2}$ was used (Hornung and Reed, 1990).

a,b,c,d,e Different letters correspond to statistically different median ( $p<0.05$; non-parametric Mann-Whitney $U$ test) between each group.

* Detection frequency of each compound was $100 \%$ (unless otherwise indicated);

\# $80 \% \leq$ detection frequency $<100 \%$.

${ }^{\alpha} 60 \% \leq$ detection frequency $<80 \%$.

\& $15 \% \leq$ detection frequency $<60 \%$.

+ Detection frequency $<15 \%$.

of the studied subjects of this work were well below the recommended guideline. However, it is necessary to remark that Nap (as well as other light-molecular weight PAHs with 2-3 aromatic rings) is predominantly found in the gas phase (Oliveira et al., 2015b, 2016b), which was not assessed in this work; thus the respective exposures of studied subjects at five fire corporations might be underestimated. Therefore, to adequately evaluate occupational exposure to PAHs (even during nonfires settings), future works should consider assessment of gaseous PAHs that are commonly not considered (Lui et al., 2017; Montaño-Soto et al., 2017; Oliveira et al., 2015a). At IZD, VFR and AFF, Phe was the $3^{\text {rd }}$ (and $4^{\text {th }}$ at IZD) most predominant compound (6-9\% of $\mathrm{EPAHs}$ ). At stations VMS and MCC, slightly different profiles of PAHs in breathing zones of workers were observed with high contributions of Ace ( $43 \%$ and $55 \%$ of $\Sigma P A H s$ ); the contribution of Nap was 6 and $10 \%$ respectively. Overall, light molecular weight PAHs (i.e. with $2-3$ rings) were by far the most predominant congeners in the breathing zones of the workers at all stations, with the abundances ranging from $74 \%$ (at VFR) to $96 \%$ (at VFS) of the total PAH content. PAHs with 5-6 rings accounted for much less content (3-9\% of $\mathrm{PAH}$ ) with the exception to VFR, where heavy molecular PAHs exhibited higher proportion (21\% of $\Sigma P A H s$ ). This occurrence was mostly due to the higher contributions of D $[a, h] \mathrm{A}$ (6\% of $\Sigma \mathrm{PAHs}$ at VFR $v s . \sim 1 \%$ at the other fire houses) and $\mathrm{B}[$ ghi] $\mathrm{P}$ ( $8 \%$ at VFR vs. $\sim 2-4 \%$ at the remaining corporations). The higher prevalence of these two PAHs indicates a potential contribution from vehicular emissions (Ravindra et al., 2008) at this fire station.

Occupational Safety and Health Administration (OSHA) regulates occupational exposure to PAHs through "coal tar pitch volatiles" (ATSDR, 2016; i.e. extractable benzene soluble fraction of total particulates that includes $\mathrm{B}[a] \mathrm{A}, \mathrm{B}[b] \mathrm{F}$, Chry, Ant, B $[a] \mathrm{P}$, Phe, Pyr and acridine) (Table 6S). The designated limit is expressed as 8-hour time-weighted average (TWA) permissible exposure limit (PEL) of $0.2 \mathrm{mg} \mathrm{m}^{-3}$ (ATSDR, 2016). The National Institute for Occupational Safety and Health (NIOSH) guideline for PAHs exposure in the workplaces is set as the lowest detectable concentration of $0.1 \mathrm{mg} \mathrm{m}^{-3}$ for coal tar pitch volatile agents (ATSDR, 2016). The air exposure to these seven PAHs (acridine was not considered in this work) ranged between 4.7 and $46 \mathrm{ng} \mathrm{m}^{-3}$ among the investigated subjects being well below the OSHA-mandated limit and NIOSH recommendation. The permitted $\left(0.6 \mathrm{mg} \mathrm{m}^{-3}\right)$ and maximum $\left(1 \mathrm{mg} \mathrm{m}^{-3}\right)$ excursion limits defined by American Conference of Governmental Industrial Hygienists (ACGIH; Table 6S) were also fulfilled for total PAHs.

Occupational exposure of firefighters has been associated with increased risk of cancers (urothelial, skin, lung, kidney and testicular cancers) though some findings remain unclear (Daniels et al., 2013; LeMasters et al., 2006). Once absorbed into blood stream (by inhalation, ingestion, and dermal contact) PAHs are metabolized and distributed 
within the human body, being mostly eliminated through the urine in the form of glucuronide and sulphate conjugates (Kamal et al., 2015). Within this biological process, some reactive metabolites are formed and tend to bind with some macromolecules, including the DNA, thus leading to the formation of mutations and tumours that can evolve to cancer (Abdel-Shafy and Mansours, 2016). Out of 18 analysed PAHs, nine are considered as possible or probable carcinogens (IARC, 2002, 2010b) (Nap, B[a]A, Chry, B $[b] \mathrm{F}, \mathrm{B}[j] \mathrm{F}, \mathrm{B}[k] \mathrm{F}, \mathrm{D}[a, l] \mathrm{P}, \mathrm{D}[a, h] \mathrm{A}$ and InP) whereas $\mathrm{B}[a] \mathrm{P}$ is classified as human known (class 1 ) carcinogen. Regarding the obtained levels, the highest median of $\Sigma \mathrm{PAHs} \mathrm{s}_{\mathrm{carc}}$ was observed at IZD (20.2 $\left.\mathrm{ng} \mathrm{m}^{-3}\right)$ being rather similar $(p=0.129-0.796)$ at the remaining fire corporations (12.7-14.0 $\mathrm{ng} \mathrm{m}^{-3}$ ). These concentrations ranged from $8.2 \%$ (VMS) to $27 \%$ of $\Sigma$ PAHs (at VFR) (Fig. 2a). Nap (Fig. $2 \mathrm{~b}$ ) was the most predominant carcinogen and accounted for $44 \%$

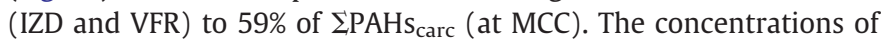
this carcinogenic obtained in the breathing zones of the characterized firefighters were below the recommended guidelines of $50 \mathrm{mg} \mathrm{m}^{-3}$ designated by NIOSH for the occupational exposure (Table 6S). $\mathrm{D}[a, h] \mathrm{A}$ was the another abundant carcinogenic PAH (accounted for 9-22\% of $\Sigma$ PAHs carc $_{\text {c }}$ at IZD, VFR and AFF) being followed by $B[b+j] F$ $\left(2-12 \%\right.$ of $\left.\Sigma P A H s_{\text {carc }}\right)$. Finally, B $[a] \mathrm{P}$ accounted for $2-8 \%$ of $\Sigma P A H s_{\text {carc }}$. Its levels in breathing zone of firefighters (in non-fire settings) fulfilled the ambient air guideline of $1 \mathrm{ng} \mathrm{m}^{-3}$ (Directive 2004/107/EC, 2005) (as no specific occupational guideline is established for this PAH).

\subsection{Source identification}

Fig. 3 shows principal component analysis (PCA) for PAHs data set obtained in this work. Factors with eigenvalues $>1$ were extracted and Kaiser-Meyer-Olkin measure of sampling adequacy $>0.5$ was used (B[a]A was excluded as it presented value $<0.5$ ). The PCA model resulted in two significant factors (F1 and F2) that represented $74.70 \%$ of the total variability (Table 7 S). F1 contributed $42.53 \%$ of the original data with high loadings (square cosines values $>0.712$ ) for Flu, Phe, Ant, Fln, Pyr, Chry, and B[ghi]P. This factor allowed discrimination of mainly subjects of IZD fire stations from the other corporations, and in some extend also from VMS. High loadings of Flu, Ant, Fln and Pyr indicates wood combustion or biomass burning (Deka et al., 2016; Lu et al., 2016). Coal combustion also release PAHs such as Phe and Chry (Deka et al., 2016; Harrison et al., 1996; Ho et al., 2002; Simcik et al., 1999). High loadings of Fln, Pyr and B[ghi]P were also reported for vehicular emissions (Khalili et al., 1995). The values obtained for Fln/ $($ Fln + Pyr) diagnostic ratio (Table 3), that can differentiate between coal combustion $(0.52)$ and vehicular emissions $(0.40-0.50)$, points

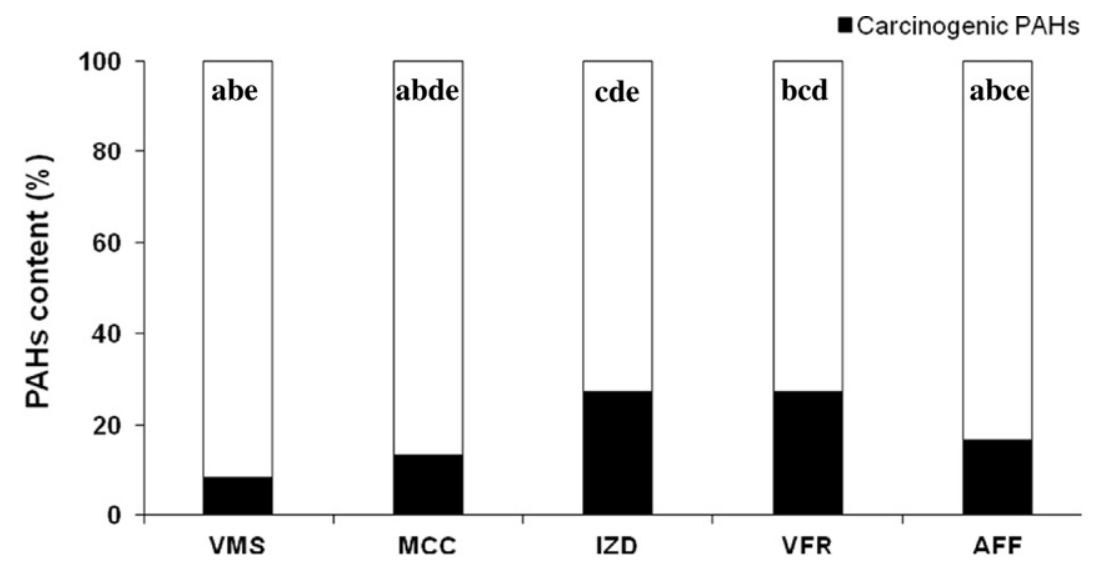

(a)

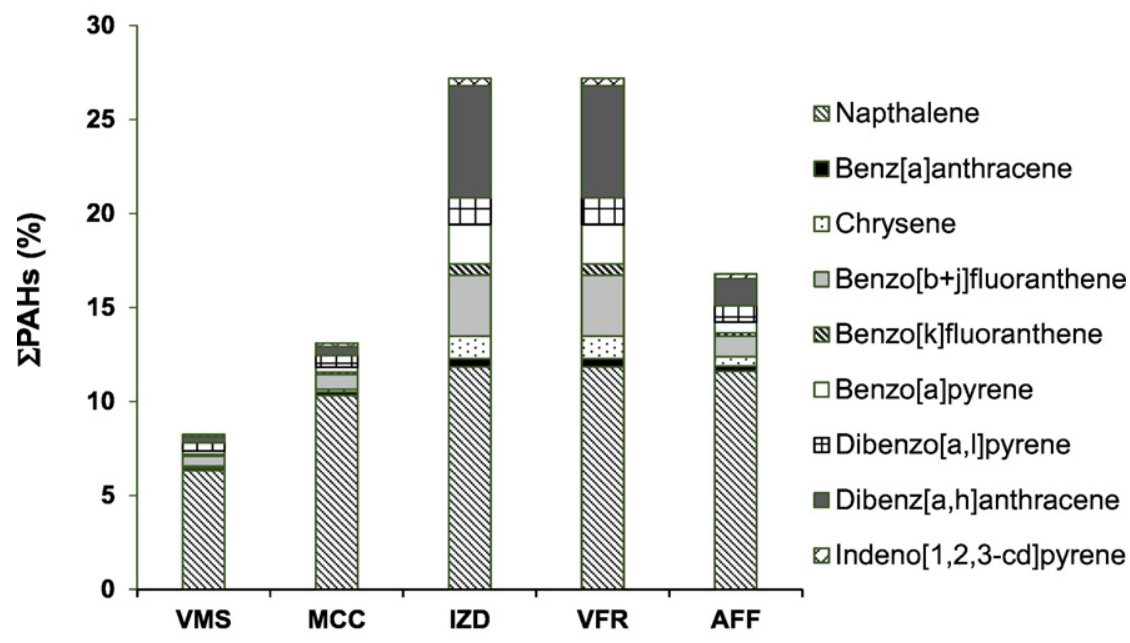

(b)

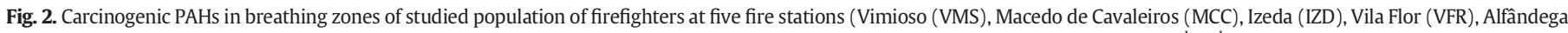

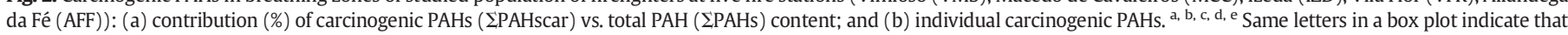
given means are not statistically different ( $p>0.05$ ( $p<0.05$; non-parametric Mann-Whitney $U$ test). 


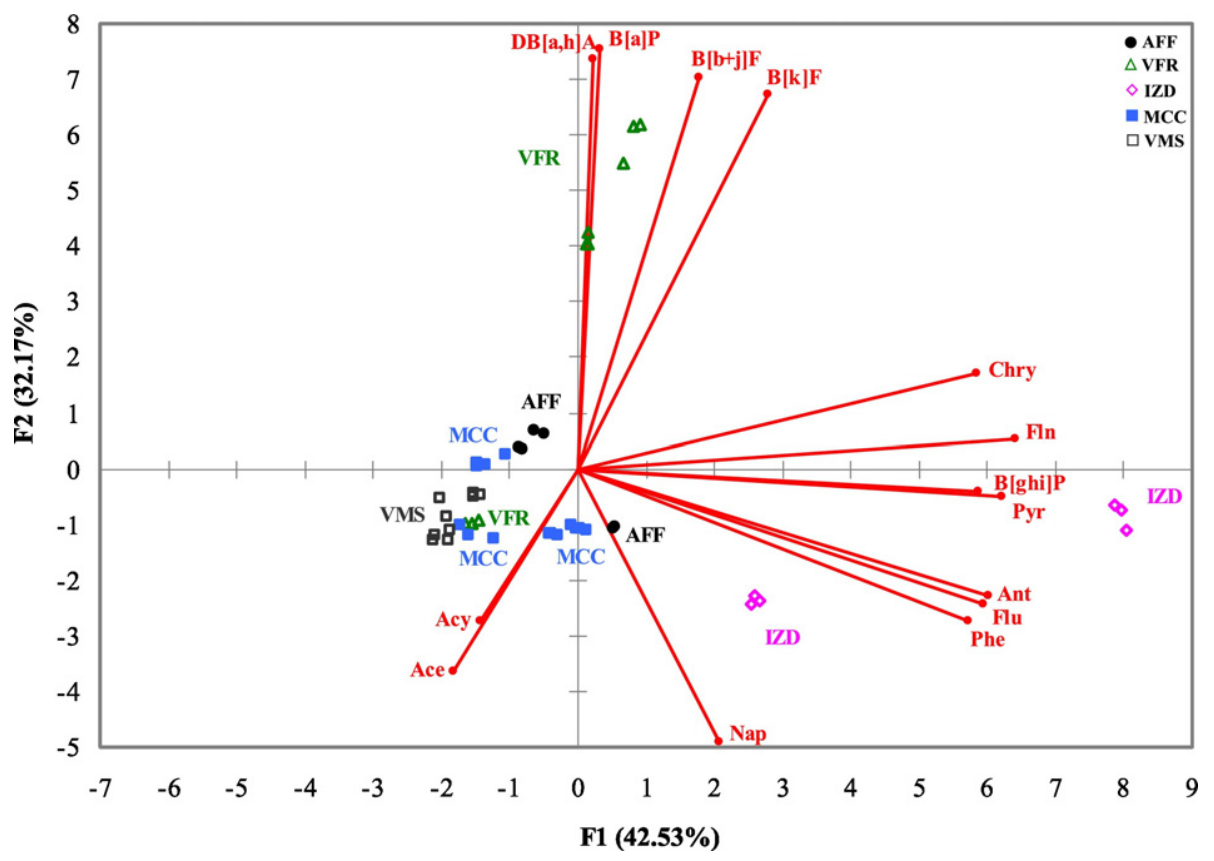

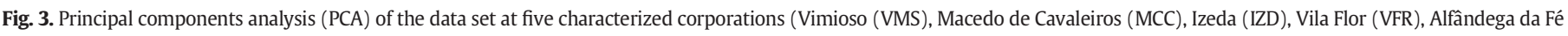
$(\mathrm{AFF}))$ ) based on concentrations of selected PAHs.

towards the latter source; the respective values ranged between 0.40 (at AFF) and 0.50 (at VMS). However, the results of $\operatorname{InP} /(\operatorname{InP}+\mathrm{B}[$ ghi $] \mathrm{P}$ (distinguishes between vehicular emissions, wood, and coal combustions; Kavouras et al., 2001; Rogge et al., 1993a; Sicre et al., 1987; Grimmer et al., 1983; Pio et al., 2001) and B[ghi] P/B $[a] \mathrm{P}$ (vehicular emissions vs. road dust; Oda et al., 2001; Rogge et al., 1993a, 1993b) were inconclusive. Thus, it seems that $\mathrm{F} 1$ represented contributions from mixed sources. It is though necessary to remark that both these ratios contained B[ghi]P, a considered marker of vehicular (diesel) emissions. However, some studies that investigated PAHs origin in different Portuguese metropolitan areas (Alves et al., 2016; Cachada et al., 2012; Castro et al., 2009; Slezakova et al., 2010, 2011, 2013a, 2013b), did not report $\mathrm{B}[$ ghi $] \mathrm{P}$ as the predominant compound (though it was abundant, and traffic emissions were identified as the major source). Instead, the authors reported higher abundances of other indicators: Pyr, $B[b+j] F$, D[a,h]A (Callén et al., 2013; Ravindra et al., 2008).

F2 represented $32.17 \%$ of the original data variance and allowed the discrimination of VFR individuals from the others. F2 was highly loaded (square cosines $>0.747$ ) for $\mathrm{B}[\mathrm{b}+\mathrm{j}] \mathrm{F}, \mathrm{B}[k] \mathrm{F}, \mathrm{B}[a] \mathrm{P}$ and $\mathrm{DB}[a h] \mathrm{A}$ ), and much less for Nap (square cosines value of 0.389). The high loadings of $\mathrm{B}[b] \mathrm{F}$ and $\mathrm{B}[a] \mathrm{P}$ were reported for gasoline emissions (Chen et al., 2016; Guo et al., 2003), whereas high loadings of $\mathrm{B}[k] \mathrm{F}, \mathrm{B}[a] \mathrm{P}$ and $\mathrm{DB}[a h] \mathrm{A}$ are indicative of diesel emissions (Ravindra et al., 2008; Teixeira et al., 2013). In general, vehicular emissions are a common major source of PAHs in ambient air (Slezakova et al., 2010, 2013a, 2013b) and indoor infiltrations result from poorly fitted windows, doors, building cracks, and ventilation systems (WHO, 2010). In agreement, B[a]A/Chry (>0.35 at all fire houses) indicated fuel combustion and car exhausts (Krugly et al., 2014) and the values of $\mathrm{B}[b] \mathrm{F} / \mathrm{B}[k] \mathrm{F}$ ratios $(>0.5$ at all fire corporations) also pointed towards impacts of traffic emissions at the fire houses, specifically from diesel emissions (Ravindra et al., 2008). These findings were expected. Firstly, diesel is the most used car fuel in Portugal ( $~ 80 \%$ of the total car fuel consumption; INE, 2015), and secondly it was the fuel used for vehicles and firefighting trucks in all fire facilities. The ambient air emissions and car exhausts (from garages/truck bays) may infiltrate indoors (to living quarters, common areas and control centers). Nevertheless, $\mathrm{B}[\mathrm{b}+\mathrm{k}] \mathrm{F} / \mathrm{-}$ $\mathrm{B}[$ ghi $] \mathrm{P}$ that can differentiate between various vehicle emissions (1.60: diesel; 0.33: gasoline; Li and Kamens, 1993) indicated a contribution mostly from gasoline exhausts at all fire corporations. In addition, $\mathrm{B}[a] \mathrm{P} /(\mathrm{B}[a] \mathrm{P}+$ Chry $)$ and $\mathrm{Flu} /(\mathrm{Flu}+\mathrm{Pyr})$ ratios that can also be used to distinguish between both types of exhausts (Ravindra et al., 2008) suggested predominance of gasoline emissions at VFR, diesel emissions at IZD, and mixed contribution from both diesel and gasoline emissions at firehouses VMS, MCC and AFF.

Nap results from unburned fossil derived fuel or alkyl substituted PAHs and indicates petrogenic source (Chen et al., 2016). In addition, petrogenic origin of unburned petroleum, gasoline and diesel emissions have been reported for dominant 2- and 3-ring PAHs (Yunker et al., 2002). In agreement, the diagnostic ratios of low molecular PAHs vs. high molecular weight congeners (Table 3 ) were $>1$ indicating contributions of petrogenic sources at all fire corporations. Petrogenic sources were also identified with Phe/(Phe + Ant) values $>0.7$, implying the use of lubricant oils (Mirante et al., 2013). F2 thus represented a mixed contribution of petrogenic and pyrogenic sources. Still, it is necessary to emphasize that diagnostic ratios are merely rudimentary indicators of PAHs origin (Galarneau, 2008). Numerous studies have highlighted the limitations of this method as values can be altered to a different extent due to environmental degradation and phase transfers (Dvorská et al., 2011; Galarneau, 2008; Katsoyiannis et al., 2007, 2011; Tobiszewski and Namieśnik, 2012; Usenko et al., 2010) and/or reactions between PAHs and other gaseous pollutants (ozone, nitrogen oxides; Ravindra et al., 2008). Some of the technical literature concerning PAHs emission signatures is rather old and lacks information on molecular signatures of new generation vehicles, biomass burning technologies, boilers and waste treatment plants (Finardi et al., 2015); the available reference values of currently used diagnostic ratios may be unusable to clearly assign PAHs to specific sources.

\subsection{Risk assessment of PAHs}

Because of its high TEF, D[a,h]A was the predominant PAH to $\Sigma \mathrm{B}[a] \mathrm{P}_{\mathrm{eq}}(\sim 80 \%$ at VMS, MCC and IZD; 90\% at VFR and AFF; Table 4$)$ being followed by B[a]P (6-7\% at VFR and AFF; 9\% VMS, MCC and IZD). $\mathrm{B}[a] \mathrm{P}_{\text {eq }}$ were also assessed using TEF values by Muller (Boström et al., 2002; Table 8S) who included D[a,l]P (TEF of 100); this PAH was the largest contributor (95-99\%) to $\Sigma \mathrm{B}[a] \mathrm{P}_{\mathrm{eq}}$. Despite strong arguments that support monitoring and assessment of $\mathrm{D}[a, l] \mathrm{P}$ (Boström et al., 2002; 
Table 3

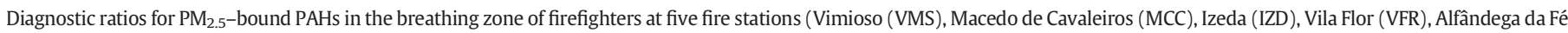
(AFF)).

\begin{tabular}{|c|c|c|c|c|c|c|c|c|}
\hline \multirow[t]{2}{*}{ Ratio } & \multicolumn{5}{|c|}{ This study } & \multirow[t]{2}{*}{ Value } & \multirow[t]{2}{*}{ Source } & \multirow[t]{2}{*}{ Reference } \\
\hline & VMS & MCC & IZD & VFR & AFF & & & \\
\hline$\Sigma \mathrm{PAHs}_{\mathrm{LMW}} / \Sigma \mathrm{PAH}_{\mathrm{SHMW}}{ }^{\mathrm{a}}$ & $\begin{array}{l}30.9 \\
\pm 13.5\end{array}$ & $\begin{array}{l}16.1 \\
\pm 6.8\end{array}$ & $\begin{array}{l}7.0 \\
\pm 4.3\end{array}$ & $\begin{array}{l}5.8 \\
\pm 4.0\end{array}$ & $\begin{array}{l}9.3 \\
\pm 4.4\end{array}$ & $\begin{array}{l}>1 \\
<1\end{array}$ & $\begin{array}{l}\text { Petrogenic } \\
\text { Pyrogenic }\end{array}$ & (Zhang et al., 2008) \\
\hline Fln $/($ Fln + Pyr $)$ & $\begin{array}{l}0.50 \\
\pm 0.09\end{array}$ & $\begin{array}{l}0.46 \\
\pm 0.09\end{array}$ & $\begin{array}{l}0.48 \\
\pm 0.07\end{array}$ & $\begin{array}{l}0.44 \\
\pm 0.26\end{array}$ & $\begin{array}{l}0.40 \\
\pm 0.16\end{array}$ & $\begin{array}{l}0.40-0.5 \\
>0.5 \\
0.42,0.52\end{array}$ & $\begin{array}{l}\text { Vehicular } \\
\text { traffic } \\
\text { Coal } \\
\text { combustion } \\
\text { Road dust }\end{array}$ & $\begin{array}{l}\text { (Kavouras et al., 1999; Yunker et al., 2002; Zencak et al., 2007; Rogge } \\
\text { et al., 1993a; Oda et al., 2001) }\end{array}$ \\
\hline $\operatorname{InP} /(\operatorname{InP}+\mathrm{B}[$ ghi $] \mathrm{P})$ & $\begin{array}{l}0.06 \\
\pm 0.04\end{array}$ & $\begin{array}{l}0.05 \\
\pm 0.03\end{array}$ & $\begin{array}{l}0.03 \\
\pm 0.01\end{array}$ & $\begin{array}{l}0.10 \\
\pm 0.08\end{array}$ & $\begin{array}{l}0.07 \\
\pm 0.06\end{array}$ & $\begin{array}{l}0.21-0.22 \\
0.35-0.70 \\
0.56 \\
0.62 \\
0.36\end{array}$ & $\begin{array}{l}\text { Gasoline cars } \\
\text { Diesel } \\
\text { emissions } \\
\text { Coal } \\
\text { combustion } \\
\text { Wood } \\
\text { combustion } \\
\text { Road dust }\end{array}$ & $\begin{array}{l}\text { (Gogou et al., 1996; Grimmer et al., 1983; Kavouras et al., 2001; Pio et al., } \\
\text { 2001; Ravindra et al., 2008; Rogge et al., 1993a; Sicre et al., 1987) }\end{array}$ \\
\hline $\mathrm{B}[$ ghi $] \mathrm{P} / \mathrm{B}[a] \mathrm{P}$ & $\begin{array}{l}12.6 \\
\pm 9.6\end{array}$ & $\begin{array}{l}13.4 \\
\pm 4.6\end{array}$ & $\begin{array}{l}22.7 \\
\pm 4.5\end{array}$ & $\begin{array}{l}6.0 \\
\pm 3.9\end{array}$ & $\begin{array}{l}8.0 \\
\pm 2.2\end{array}$ & $\begin{array}{l}1.2-2.2 \\
2.5-3.3 \\
0.86,0.91\end{array}$ & $\begin{array}{l}\text { Diesel cars } \\
\text { Gasoline cars } \\
\text { Road dust }\end{array}$ & (Oda et al., 2001; Rogge et al., 1993a, 1993b) \\
\hline $\mathrm{B}[\mathrm{a}] \mathrm{A} /$ Chry & $\begin{array}{l}2.36 \\
\pm 1.88\end{array}$ & $\begin{array}{l}1.25 \\
\pm 0.32\end{array}$ & $\begin{array}{l}0.80 \\
\pm 0.87\end{array}$ & $\begin{array}{l}0.87 \\
\pm 0.63\end{array}$ & $\begin{array}{l}0.64 \\
\pm 0.56\end{array}$ & $>0.35$ & $\begin{array}{l}\text { Fuel } \\
\text { combustion }\end{array}$ & (Krugly et al., 2014) \\
\hline $\mathrm{B}[b] \mathrm{F} / \mathrm{B}[k] \mathrm{F}$ & $\begin{array}{l}8.1 \\
\pm 3.6\end{array}$ & $\begin{array}{l}6.3 \\
\pm 2.3\end{array}$ & $\begin{array}{l}5.5 \\
\pm 1.18\end{array}$ & $\begin{array}{l}6.3 \\
\pm 1.1\end{array}$ & $\begin{array}{l}6.0 \\
\pm 0.5\end{array}$ & $>0.5$ & Diesel & (Ravindra et al., 2008) \\
\hline $\mathrm{B}[a] \mathrm{A} /(\mathrm{B}[a] \mathrm{A}+$ Chry $)$ & $\begin{array}{l}0.64 \\
\pm 0.13\end{array}$ & $\begin{array}{l}0.55 \\
\pm 0.07\end{array}$ & $\begin{array}{l}0.38 \\
\pm 0.31\end{array}$ & $\begin{array}{l}0.41 \\
\pm 0.20\end{array}$ & $\begin{array}{l}0.40 \\
\pm 0.19\end{array}$ & $\begin{array}{l}0.40, \\
0.38-0.64 \\
0.76 \\
0.43\end{array}$ & $\begin{array}{l}\text { Diesel } \\
\text { Gasoline } \\
\text { Wood } \\
\text { combustion }\end{array}$ & (Li and Kamens, 1993; Manoli et al., 2004; Sicre et al., 1987) \\
\hline $\mathrm{B}[\mathrm{b}+\mathrm{k}] \mathrm{F} / \mathrm{B}[g h i] \mathrm{P}$ & $\begin{array}{l}0.41 \\
\pm 0.15\end{array}$ & $\begin{array}{l}0.30 \\
\pm 0.15\end{array}$ & $\begin{array}{l}0.19 \\
\pm 0.01\end{array}$ & $\begin{array}{l}0.45 \\
\pm 0.12\end{array}$ & $\begin{array}{l}0.30 \\
\pm 0.04\end{array}$ & $\begin{array}{l}1.60 \\
0.33 \\
2.18\end{array}$ & $\begin{array}{l}\text { Diesel cars } \\
\text { Gasoline cars } \\
\text { Wood } \\
\text { combustion }\end{array}$ & (Li and Kamens, 1993) \\
\hline $\mathrm{B}[a] \mathrm{P} /(\mathrm{B}[a] \mathrm{P}+$ Chry $)$ & $\begin{array}{l}0.71 \\
\pm 0.11\end{array}$ & $\begin{array}{l}0.66 \\
\pm 0.07\end{array}$ & $\begin{array}{l}0.49 \\
\pm 0.37\end{array}$ & $\begin{array}{l}0.72 \\
\pm 0.17\end{array}$ & $\begin{array}{l}0.52 \\
\pm 0.22\end{array}$ & $\begin{array}{l}0.5 \\
0.73\end{array}$ & $\begin{array}{l}\text { Diesel } \\
\text { Gasoline }\end{array}$ & (Ravindra et al., 2008) \\
\hline $\mathrm{Flu} /(\mathrm{Flu}+\mathrm{Pyr})$ & $\begin{array}{l}0.59 \\
\pm 0.22\end{array}$ & $\begin{array}{l}0.60 \\
\pm 0.19\end{array}$ & $\begin{array}{l}0.53 \\
\pm 0.16\end{array}$ & $\begin{array}{l}0.39 \\
\pm 0.11\end{array}$ & $\begin{array}{l}0.44 \\
\pm 0.08\end{array}$ & $\begin{array}{l}>0.5 \\
<0.5\end{array}$ & $\begin{array}{l}\text { Diesel } \\
\text { Gasoline }\end{array}$ & (Ravindra et al., 2008) \\
\hline Phe/(Phe + Ant) & $\begin{array}{l}0.95 \\
\pm 0.03\end{array}$ & $\begin{array}{l}0.95 \\
\pm 0.01\end{array}$ & $\begin{array}{l}0.97 \\
\pm 0.01\end{array}$ & $\begin{array}{l}0.95 \\
\pm 0.03\end{array}$ & $\begin{array}{l}0.96 \\
\pm 0.01\end{array}$ & $>0.7$ & $\begin{array}{l}\text { Lubricant oils } \\
\text { and fossil fuels }\end{array}$ & (Mirante et al., 2013) \\
\hline
\end{tabular}

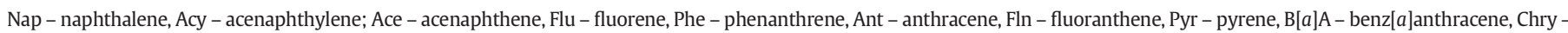

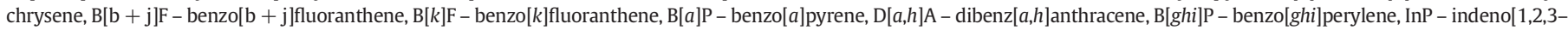
cd]pyrene;

a Total concentration of 2- and 3-rings PAHs ( 2 PAHs $\left.\mathrm{LMw}_{\mathrm{L}}\right)$, and 4-6-rings PAHs ( $\left.\mathrm{ZPAHs}_{\mathrm{HMw}}\right)$;

Okona-Mensah et al., 2005), these findings need to be carefully implied as at all fire stations $\mathrm{D}[a, l] \mathrm{P}$ levels were below its LOD (Table 2). Nap ( 6-16\% of $\Sigma$ PAHs; Table 2 ) contributed $<1 \%$ to $\Sigma \mathrm{B}[a] \mathrm{P}_{\mathrm{eq}}$ (Table 4 and $8 \mathrm{~S})$.

At all fire corporations lung cancer risks $\left(8.9 \times 10^{-5}-4.4 \times 10^{-4}\right)$ exceeded (9-44 times) the WHO health-based recommend guideline of $10^{-5}$ (Boström et al., 2002).

Total ILR (Fig. 4) were the lowest at MCC (median of $1.94 \times 10^{-8}$ ) and the highest at AFF (median of $1.22 \times 10^{-7}$ ); the remaining three fire corporations exhibited similar levels $(p=437-0.630)$ risks. Both total and individual ILR (Table 9S) were $<10^{-6}$ and thus considered as negligible. Corporations VMS and VFR exhibited higher ILR ranges than at other stations. At VMS, high ILR maxima were caused by long exposure duration of firefighting subjects (employed $>25$ years; Table 1 ). At VFR, high values were due to overall higher exposure of some subjects ( $\Sigma$ PAHs up to $731 \mathrm{ng} \mathrm{m}^{-3}$ ). ILR profiles of these subjects (results not shown) were dominated by $\mathrm{D}[a, h] \mathrm{A}(70 \%), \mathrm{B}[a] \mathrm{P}(18 \%), \mathrm{B}[\mathrm{j}+\mathrm{j}] \mathrm{F}$ (3\%). These PAHs (considered as traffic emissions markers) were the major contributors to F2 of PCA (Fig. 3) and allowed differentiation (67\%) of VFR subjects; the respective workers spent majority of their shift in garage/truck bays (repair tasks). Nap contributed $23 \%$ of total ILR ( $11 \%$ at VFR - 34\% at IZD). It needs to be emphasize that in a view of its existing guidelines (occupational exposure and indoor air quality),
Table 4

Toxicity equivalent concentrations based on toxicity of benzo $[a]$ pyrene $(\mathrm{B}[\mathrm{a}] \mathrm{P} \mathrm{eq})$ of $\mathrm{PM}_{2.5}$ bound PAHs ( $\mathrm{pg} \mathrm{m}^{-3}$ ) in the breathing air zone of firefighters at five fire stations (Vimioso (VMS), Macedo de Cavaleiros (MCC), Izeda (IZD), Vila Flor (VFR), Alfândega da Fé (AFF)) using toxic equivalency factors (TEF) set by Nisbeth and LaGoy (Boström et al., 2002).

\begin{tabular}{|c|c|c|c|c|c|c|}
\hline Compound & TEF & VMS & MCC & IZD & VFR & AFF \\
\hline Naphthalene & 0.001 & 9.78 & 11.01 & 16.33 & 5.54 & 8.98 \\
\hline Acenaphthylene & 0.001 & 68.70 & 24.01 & 37.26 & 24.01 & 53.02 \\
\hline Acenaphthene & 0.001 & 65.79 & 58.22 & 25.01 & 1.62 & 1.62 \\
\hline Fluorene & 0.001 & 0.40 & 0.67 & 1.36 & 0.27 & 0.70 \\
\hline Phenanthrene & 0.001 & 3.54 & 4.51 & 9.55 & 3.14 & 4.35 \\
\hline Anthracene & 0.01 & 2.23 & 2.23 & 3.30 & 2.23 & 2.23 \\
\hline Fluoranthene & 0.001 & 0.35 & 0.35 & 1.82 & 0.72 & 0.60 \\
\hline Pyrene & 0.001 & 0.29 & 0.57 & 2.24 & 0.55 & 0.72 \\
\hline Benz $[a]$ anthracene & 0.1 & 20.50 & 20.50 & 25.65 & 20.50 & 20.50 \\
\hline Chrysene & 0.01 & 1.45 & 1.45 & 9.37 & 5.61 & 3.90 \\
\hline Benzo[b $+\mathrm{j}]$ fluoranthene & 0.1 & 84.43 & 84.43 & 84.43 & 151.3 & 84.43 \\
\hline Benzo[k]fluoranthene & 0.1 & 13.39 & 13.39 & 18.06 & 28.11 & 13.39 \\
\hline Benzo[a]pyrene & 1 & 276.5 & 276.5 & 276.5 & 977.5 & 448.5 \\
\hline Dibenzo[a,l]pyrene & n.a. & & & & & \\
\hline Dibenz $[a, h]$ anthracene & 5 & 2495 & 2495 & 2495 & 13,933 & 5566 \\
\hline Benzo[ghi]perylene & 0.01 & 25.02 & 41.62 & 62.34 & 35.19 & 31.35 \\
\hline Indeno[1,2,3-cd]pyrene & 0.1 & 18.53 & 18.53 & 18.53 & 18.53 & 18.53 \\
\hline$\Sigma \mathrm{B}[a] \mathrm{P}_{\mathrm{eq}}$ & - & 3086 & 3053 & 3087 & 15,208 & 6260 \\
\hline$\Sigma \mathrm{B}[a] \mathrm{P}_{\text {eqcarc }}$ & - & 2920 & 2921 & 2944 & 15,140 & 6165 \\
\hline
\end{tabular}

n.a. not available. 


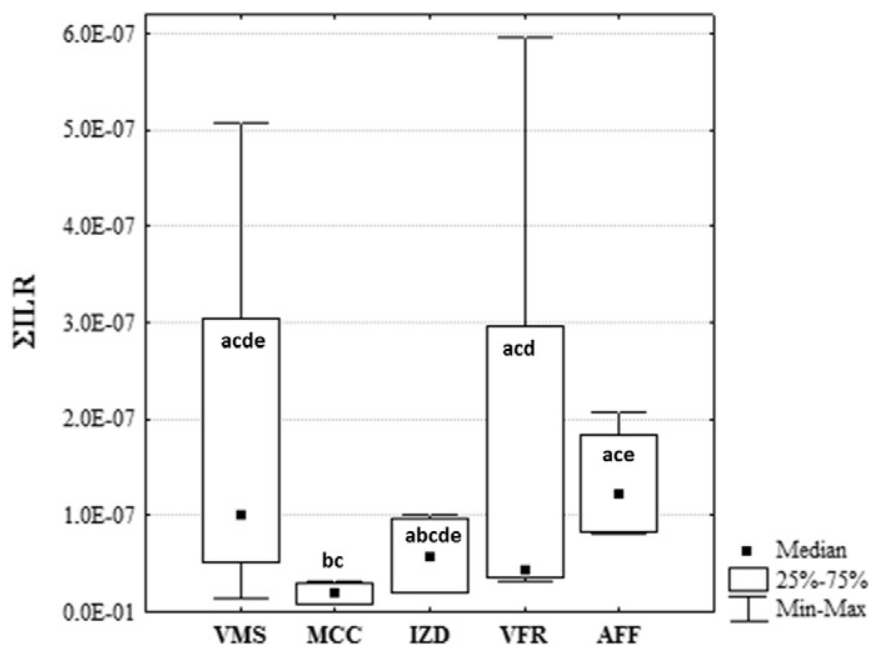

Fig. 4. Incremental lifetime cancer risks ( ILR; Median; $\square 25-75 \%$, and $T$ range) in breathing zones of studied population of firefighters at five fire stations (Vimioso (VMS), Macedo de Cavaleiros (MCC), Izeda (IZD), Vila Flor (VFR), Alfândega da Fé (AFF)). a, b, c,

$\mathrm{d}$, e Same letters in a box plot indicate that given means are not statistically different ( $p>0.05$; non-parametric Mann-Whitney $U$ test).

Nap should be routinely monitored when assessing the respective risks. Finally, the risk analysis of Nap might be underestimated to some extent; unlike other considered PAHs (B[a]A, Chry, B $[b] \mathrm{F}, \mathrm{B}[k] \mathrm{F}, \mathrm{B}[a] \mathrm{P}$, $\mathrm{D}[a, h] \mathrm{A}$ and $\mathrm{InP})$ Nap is predominantly present in vapour phase (Castro et al., 2011; Ravindra et al., 2006, 2008; Slezakova et al., 2011) which was not included in this work.

\section{Conclusions}

This study reports information concerning occupational exposure to PAHs for firefighters in non-fire settings once limited information (and from non-European) settings exists. The obtained levels of PAHs fulfilled all existent occupational exposure limits as well air quality guidelines. Light molecular weight PAHs (2-3 rings) were the most predominant congeners (74-96\% of $\Sigma_{\text {PAHs }}$ ) whereas compounds with 5-6 rings accounted for much less content (3-9\% of $\Sigma$ PAHs). The source analysis indicated mixed contributions from pyrogenic and petrogenic sources (fuel and wood combustions, vehicular emissions from both diesel and gasoline fuelled cars, and usage of lubricant oils) for personal PAHs exposure at the studied fire corporations.

The incremental lifetime cancer risks (based on USEPA methodology) due to exposure to airborne PAHs were below the recommend guideline of $10^{-6}$ and thus can be considered as negligible for studied subjects. However, WHO health-based guideline level of $10^{-5}$ was exceeded at all five fire corporations (9-44 times). Therefore, the respective exposures to these compounds should be carefully controlled for these occupational settings. From the health perspective, monitoring of the potential occupational health effects should be carried on in order to better understand $\mathrm{PAH}$ quantitative exposure-response relationships.

Finally, the present study included assessment of occupational exposure to PAHs during a summer season when the risks and frequency of forest fires are the highest. However, as demonstrated, atmospheric emissions impacted on background levels of occupational exposure of firefighters. Therefore, future studies evaluating occupational exposure should be also conducted during cold seasons when concentrations of ambient PAHs are increased, typically due to house heating emissions.

\section{Funding}

This work was supported by European Union (FEDER funds through COMPETE) and National Funds (Fundação para a Ciência e Tecnologia) through projects UID/QUI/50006/2013, POCI/01/0145/FEDER/007265 and UID/EQU/00511/2013, by the FCT/MEC with national funds and co-funded by FEDER in the scope of the P2020 Partnership Agreement. Additional financial support was provided by Fundação para Ciência e Tecnologia through fellowships SFRH/BD/80113/2011 and SFRH/BPD/ $105100 / 2014$.

\section{Ethical statement}

All participants of the study were informed and signed the respective consent forms.

\section{Acknowledgments}

This work was supported by European Union (FEDER funds through COMPETE) and National Funds (Fundação para a Ciência e Tecnologia) through projects UID/QUI/50006/2013, POCI/01/0145/FEDER/007265 and UID/EQU/00511/2013-LEPABE, by the FCT/MEC with national funds and co-funded by FEDER in the scope of the P2020 Partnership Agreement. Additional financial support was provided by Fundação para Ciência e Tecnologia through fellowships SFRH/BD/80113/2011 and SFRH/BPD/105100/2014.

The authors are thankful to all firefighters involved in the study and to collaborators from Escola Superior de Saúde from Instituto Politécnico de Bragança.

\section{Appendix A. Supplementary data}

Supplementary data to this article can be found online at http://dx. doi.org/10.1016/j.scitotenv.2017.03.081.

\section{References}

Abdel-Shafy, H.I., Mansours, M.S.M., 2016. A review on polycyclic aromatic hydrocarbons: source, environmental impact, effect on human health and remediation. Egypt. J. Pet. $25,107-123$

Agency for Toxic Substances and Disease Registry (ATSDR), 2016. Environmental Health and Medicine Education - Polycyclic Aromatic Hydrocarbons, Agency for Toxic Substances and Disease Registry. (available from:). http://www.atsdr.cdc.gov/csem/ pah/docs/pah.pdf.

Alexander, B.M., Baxter, C.T., 2014. Plasticizer contamination of firefighter personal protective clothing - a potential factor in increased health risks in firefighters. J. Occup. Environ. Hyg. 11, D43-D48.

Alves, C.A., Vicente, A.M.P., Gomes, J., Nunes, T., Duarte, M., Bandowe, B.A.M., 2016. Polycyclic aromatic hydrocarbons (PAHs) and their derivatives (oxygenated-PAHs, nitrated-PAHs and azaarenes) in size-fractionated particles emitted in an urban road tunnel. Atmos. Res. 180 (1), 128-137.

Annesi-Maesano, I., Moreau, D., Caillaud, D., Lavaud, F., Le Moullec, Y., Taytard, A., Pauli, G., Charpin, D., 2007. Residential proximity fine particles related to allergic sensitisation and asthma in primary school children. Respir. Med. 101, 1721-1729.

Baxter, C.T., Hoffman, J.D., Knipp, M.J., Reponen, T., Haynes, E.N., 2014. Exposure of firefighters to particulates and polycyclic aromatic hydrocarbons. J. Occup. Environ. Hyg. 11, D85-D91.

Boffetta, P., Jourenkova, N., Gustavsson, P., 1997. Cancer risk from occupational and environmental exposure to polycyclic aromatic hydrocarbons. Cancer Causes Control 8, 444-472.

Bolstad-Johnson, D.M., Burgess, J.L., Crutchfield, C.D., Storment, S., Gerkin, R., Wilson, J.R., 2000. Characterization of firefighter exposures during fire overhaul. Am. Ind. Hyg. Assoc. J. 61 (5), 636-641.

Booze, T.F. Reinhardt, T.E., Quiring, S.J., Ottmar, R.D., 2004. A screening-level assessment of the health risks of chronic smoke exposure for wildland firefighters. J. Occup. Environ. Hyg. 1, 296-305.

Boström, C.E., Gerde, P., Hanberg A., Jernstrom, B., Johansson, C., Kyrklund, T., Rannug A., Tornqvist, M., Victorin, K., Westerholm, R., 2002. Cancer risk assessments, indicators, and guidelines for polycyclic aromatic hydrocarbons in the ambient air. Environ. Health Perspect. 10, 451-488.

Brucker, N., Charão, M.F., Moro, A.M., Ferrari, P., Bubols, G., Sauer, E., Fracasso, R., Durgante, J., Thiesen, F.V., Duarte, M.M., Gioda, A., Castro, I., Saldiva, P.H., Garcia, S.C., 2014. Atherosclerotic process in taxi drivers occupationally exposed to air pollution and co-morbidities. Environ. Res. 131, 31-38.

Burstyn, I., Kromhout, H., Partanen, T., Svane, O., Langård, S., Ahrens, W., Kauppinen, T., Stücker, I., Shaham, J., Heederik, D., Ferro, G., Heikkilä, P., Hooiveld, M., Johansen, C., Randem, B.G., Boffetta, P., 2005. Polycyclic aromatic hydrocarbons and fatal ischemic heart disease. Epidemiology 6 (6), 744-750. 
Cachada, A., Pato, P., Rocha-Santos, T., da Silva, E.F., Duarte, A.C., 2012. Levels, sources and potential human health risks of organic pollutants in urban soils. Sci. Total Environ. 430, 184-192.

Callén, M.S., López, J.M., Iturmendi, A., Mastral, A.M., 2013. Nature and sources of particle associated polycyclic aromatic hydrocarbons $(\mathrm{PAH})$ in the atmospheric environment of an urban area. Environ. Pollut. 183, 166-174.

Castro, D., Slezakova, K., Delerue-Matos, C., Alvim-Ferraz, M., Morais, S., Pereira, M.C., 2011. Polycyclic aromatic hydrocarbons in gas and particulate phases of indoor environment influenced by tobacco smoke: levels, phase distribution and health risks. Atmos. Environ. 45, 1799-1808.

Castro, D., Slezakova, K., Oliva-Teles, M.T., Delerue-Matos, C., Alvim-Ferraz, M.C., Morais, S., Pereira, M.C., 2009. Analysis of polycyclic aromatic hydrocarbons in atmospheric particulate samples by microwave-assisted extraction and liquid chromatography. J. Sep. Sci. 32, 501-510.

Chen, Y.C., Chiang, H.C., Hsu, C.Y., Yang, T.T., Lin, T.Y., Chen, M.J., Chen, N.T., Wu, Y.S., 2016. Ambient PM2.5-bound polycyclic aromatic hydrocarbons (PAHs) in Changhua County, Central Taiwan: seasonal variation, source apportionment and cancer risk assessment. Environ. Pollut. 218, 372-382.

Chen, C., Zhao, B., Zhou, W.T., Jiang, X.Y., Tan, Z.C., 2012. A methodology for predicting particle penetration factor through cracks of windows and doors for actual engineering application. Build. Environ. 47, 339-348.

Daniels, R.D., Kubale, T.L., Yiin, J.H., Dahm, M., Hales, T.R., Baris, D., Zahm, S.H., Beaumont, J.J., Waters, K.M., Pinkerton, L.E., 2013. Mortality and cancer incidence in a pooled cohort of US firefighters from San Francisco, Chicago, and Philadelphia (1950-2009). Occup. Environ. Med. 71 (6), 388-397.

Deka, J., Sarma, K.P., Hoque, R.R., 2016. Source contributions of polycyclic aromatic hydrocarbons in soils around oilfield in the Brahmaputra Valley. Ecotoxicol. Environ. Saf. 133, 281-289.

De Vos, A.J.B.M., Reisen, F., Cook, A., Devine, B., Weinstein, P., 2009. Respiratory irritants in Australian bushfire smoke: air toxics sampling in a smoke chamber and during prescribed burns. Arch. Environ. Contam. Toxicol. 56, 380-388.

Diggs, D.L., Huderson, A.C., Harris, K.L., Myers, J.N., Banks, L.D., Rekhadevi, P.V., Niaz, M.S., Ramesh, A., 2011. Polycyclic aromatic hydrocarbons and digestive tract cancers: a perspective. J. Environ. Sci. Health C Environ. Carcinog. Ecotoxicol. Rev. 29 (4), 324-357.

Directive 2004/107/EC, 2005. Directive of the European Parliament and of the council relating to arsenic, cadmium, mercury, nickel and polycyclic aromatic hydrocarbons in ambient air. Off. J. Eur. Union L23, 3-16.

Dvorská, A., Lammel, G., Klánová, J., 2011. Use of diagnostic ratios for studying source apportionment and reactivity of ambient polycyclic aromatic hydrocarbons over Central Europe. Atmos. Environ. 45, 420-427.

Estrellan, C.R., Lino, F., 2010. Toxic emissions from open burning. Chemosphere 80, 193-207.

Fabian, T.Z., Borgerson, J.L., Gandhi, P.D., Baxter, C.S., Ross, C.S., Lockey, J.E., Dalton, J.M., 2014. Characterization of firefighter smoke exposure. Fire. Technol 50, 993-1019.

Fent, K.W., Eisenberg, J., Snawder, J., Sammons, D., Pleil, J.D., Stiegel, M.A., Mueller, C., Horn, G.P., Dalton, J., 2014. Systemic exposure to PAHs and benzene in firefighters suppressing controlled structure fires. Ann. Occup. Hyg. 58, 830-845.

Fent, K.W., Eisenberg, J., Evans, D., Sammons, D., Robertson, S., Striley, C., Snawder, J., Mueller, C., Kochenderfer, V., Pleil, J., Stiegel, M., Horn, G.P., 2013. Evaluation of dermal exposure to polycyclic aromatic hydrocarbons in fire fighters. Health Hazard Evaluation Report No. 2010-0156-3196. United States Department of Health and Human Services, Centers for Disease Control and Prevention, National institute for Occupational Safety and Health.

Fent, K.W., Evans, D.E., 2011. Assessing the risk to firefighters from chemical vapors and gases during vehicle fire suppression. J. Environ. Monit. 13, 536-543.

Finardi, S., Radice, P., Cecinato, A., Gariazzo, C., Gherardi, M., Romagnoli, P., 2015. Seasonal variation of PAHs concentration and source attribution through diagnostic ratios analysis. Urban Clim. (in press). 10.1016/j.uclim.2015.12.001.

Galarneau, E., 2008. Source specificity and atmospheric processing of airborne PAHs: implications for source apportionment. Atmos. Environ. 42, 8139-8149.

Gaughan, D.M., Piacitelli, C.A., Chen, B.T., Law, B.F., Virji, M.A., Edwards, N.T., Enright, P.L., Schwegler-Berry, D.E., Leonard, S.S., Wagner, G.R., Kobzik, L., Kales, S.N., Hughes, M.D., Christiani, D.C., Siegel, P.D., Cox-Ganser, J.M., Hoover, M.D., 2014a. Exposures and cross-shift lung function declines in wildland firefighters. J. Occup. Environ. Hyg. 11, 591-603.

Gaughan, D.M., Siegel, P.D., Hughes, M.D., Chang, C.-Y., Law, B.F., Campbell, C.R., Richards, J.C., Kales, S.F., Chertok, M., Kobzik, L., Nguyen, P.-son., O'Donnell, C.R., Kiefer, M., Wagner, G.R., Christiani, D.C., 2014b. Arterial stiffness, oxidative stress, and smoke exposure in wildland firefighters. Am. J. Ind. Med. 57, 748-756.

Gogou, A., Stratigakis, N., Kanakidou, M., Stefanou, E.G., 1996. Organic aerosols in eastern Mediterranean: components source reconciliation by using molecular markers and atmospheric back trajectories. Org. Geochem. 25, 79-96.

Grimmer, G., Jacob, J., Naujack, K.W., Dettbarn, G., 1983. Determination of polycyclic aromatic compounds emitted from brown-coal-fired residential stoves by gas chromatography/gas spectrometry. Anal. Chem. 55, 892-900.

Guo, H., Lee, S.C., Ho, K.F., Wang, X.M., Zou, S.C., 2003. Particle-associated polycyclic aromatic hydrocarbons in urban air of Hong Kong. Atmos. Environ. 37, 5307-5317.

Hanedar, A., Alp, K., Kaynak, B., Avşar, E., 2014. Toxicity evaluation and source apportionment of polycyclic aromatic hydrocarbons (PAHs) at three stations in Istanbul, Turkey. Sci. Total Environ. 488-489, 437-446.

Harrison, R.M., Smith, D.J.T., Luhana, L., 1996. Source apportionment of atmospheric polycyclic aromatic hydrocarbons collected from an urban location in Birmingham, UK. Environ. Sci. Technol. 30, 825-832.

Ho, K.F., Lee, S.C., Chiu, G.M.Y., 2002. Characterization of selected volatile organic compounds, polycyclic aromatic hydrocarbons and carbonyl compounds at a roadside monitoring station. Atmos. Environ. 36, 57-65.
Hornung, R.W., Reed, L.D., 1990. Estimation of average concentration in the presence of nondetectable values. J. Occup. Environ. Hyg. 5, 46-51.

IARC Working Group on the Evaluation of Carcinogenic Risks to Humans (IARC), 2002. Some traditional herbal medicines, some mycotoxins, naphthalene and styrene. IARC Monogr. Eval. Carcinog. Risks Hum. 82, 1-556.

IARC Working Group on the Evaluation of Carcinogenic Risks to Humans (IARC), 2010a. Painting, firefighting and shiftwork. IARC Monogr. Eval. Carcinog. Risks Hum. 98 9-764.

IARC Working Group on the Evaluation of Carcinogenic Risks to Humans (IARC), 2010b. Some non-heterocyclic polycyclic aromatic hydrocarbons and some related exposures. IARC Monogr. Eval. Carcinog. Risks Hum. 92, 1-853.

Instituto Nacional de Estatística (INE), 2015. Statistical Yearbook of Norte Region 2014 Instituto Nacional de Estatística, I.P., Lisbon Portugal.

Jeng, A., Pan, C.H., Diawara, N., Chang-Chien, G.P., Lin, W.Y., Huang, C.T., Ho, C.K., Wu, M.T. 2011. Polycyclic aromatic hydrocarbon-induced oxidative stress and lipid peroxidation in relation to immunological alteration. Occup. Environ. Med. 68 (9), 653-658.

Jia, C., Batterman, S., 2010. Critical review of naphthalene sources and exposures relevant to indoor and outdoor air. Int. J. Environ. Res. Public Health 7, 2903-2939.

Joint Research Centre, 2011. Forest fires in Europe 2010. Report 11. Joint Research Centre, Institute for Environment and Sustainability, Luxembourg: Publications Office of the European Union.

Joint Research Centre, 2015. Forest fires in Europe, Middle East and North Africa 2014. JRC Technical Reports, Joint Research Centre, Institute for Environment and Sustainability, Luxembourg: Publications Office of the European Union.

Kamal, A., Cincinelli, A., Martellini, T., Malik, R.N., 2015. Review of PAH exposure from the combustion of biomass fuel and their less surveyed effect on the blood parameters. Environ. Sci. Pollut. R. 22 (6), 4076-4098.

Katsoyiannis, A., Sweetman, A.J., Jones, K.C., 2011. PAH molecular diagnostic ratios applied to atmospheric sources: a critical evaluation using two decades of source inventory and air concentration data from the UK. Environ. Sci. Technol. 45, 8897-8906.

Katsoyiannis, A., Terzi, E., Cai, Q.-Y., 2007. On the use of PAH molecular diagnostic ratios in sewage sludge for the understanding of the PAH sources. Is this use appropriate? Chemosphere 69, 1337-1339.

Kavouras, I.G., Koutrakis, P., Tsapakis, M., Lagoudaki, E., Stephanou, E.G., Von Baer, D. Oyola, P., 2001. Source apportionment of urban particulate aliphatic and polynuclear aromatic hydrocarbons (PAHs) using multivariate methods. Environ. Sci. Technol. 35, 2288-2294.

Kavouras, I.G., Lawrence, J., Koutrakis, P., Stephanou, E.G., Oyola, P., 1999. Measurement of particulate aliphatic and polynuclear aromatic hydrocarbons in Santiago de Chile: source reconciliation and evaluation of sampling artifacts. Atmos. Environ. 33, 4977-4986.

Khalili, N.R., Scheff, P.A., Holsen, T.M., 1995. PAH source fingertrips for coke ovens, diese and gasoline engines, highway tunnels, and wood combustion emissions. Atmos. Environ. 29, 533-542.

Kim, K.H., Jahan, S.A., Kabir, E., Brown, R.J., 2013. A review of airborne polycyclic aromatic hydrocarbons (PAHs) and their human health effects. Environ. Int. 60, 71-80.

Kirk, K.M., Logan, M.B., 2015a. Firefighting instructors' exposures to polycyclic aromatic hydrocarbons during live fire training scenarios. J. Occup. Environ. Hyg. 12 (4) 227-234.

Kirk, K.M., Logan, M.B., 2015b. Structural firefighting ensembles: accumulation and offgassing of combustion products. J. Occup. Environ. Hyg. 12 (6), 376-383.

Korashy, H.M., El-Kadi, A.O.S., 2006. The role of aryl hydrocarbon receptor in the pathogenesis of cardiovascular diseases. Drug Metab. Rev. 38 (3), 411-450.

Krugly, E., Martuzevicius, D., Sidaraviciute, R., Ciuzas, D., Prasauskas, T., Kauneliene, V. Stasiulaitiene, I., Kliucininkas, L., 2014. Characterization of particulate and vapor phase polycyclic aromatic hydrocarbons in indoor and outdoor air of primary schools Atmos. Environ. 82, 298-306.

Kuang, D., Zhang, W., Deng, Q., Zhang, X., Huang, K., Guan, L., Hu, D., Wu, T., Guo, H., 2013. Dose-response relationships of polycyclic aromatic hydrocarbons exposure and oxidative damage to DNA and lipid in coke oven workers. Environ. Sci. Technol. 47 (13), 7446-7456.

Laitinen, J., Mäkelä, M., Mikkola, J., Huttu, I., 2010. Fire fighting trainers' exposure to carcinogenic agents in smoke diving simulators. Toxicol. Lett. 192, 61-65.

Lee, M.S., Magari, S., Christiani, D.C., 2011. Cardiac autonomic dysfunction from occupational exposure to polycyclic aromatic hydrocarbons. Occup. Environ. Med. 68 (7), 474-478.

LeMasters, G.K., Genaidy, A.M., Succop, P., Deddens, J., Sobeih, T., Barriera-Viruet, H. Dunning, K., Lockey, J., 2006. Cancer risk among firefighters: a review and metaanalysis of 32 studies. J. Occup. Environ. Med. 48 (11), 1189-1202.

Lemieux, P.M., Lutes, C.C., Santoianni, D.A., 2004. Emissions of organic air toxics from open burning: a comprehensive review. Prog. Energ. Combust. 30, 1-32.

Lewtas, J., 2007. Air pollution combustion emissions: characterization of causative agents and mechanisms associated with cancer, reproductive, and cardiovascular effects. Mutat. Res. - Rev. Mutat. 637, 95-133.

Li, C.K., Kamens, R.M., 1993. The use of polycyclic aromatic hydrocarbons as source signatures in receptor modelling. Atmos. Environ. 27, 523-532.

Liu, S., Tao, S., Liu, W., Dou, H., Liu, Y., Zhao, J., Little, M.G., Tian, Z., Wang, J., Wang, L., Gao Y., 2008. Seasonal and spatial occurrence and distribution of atmospheric polycyclic aromatic hydrocarbons (PAHs) in rural and urban areas of the North Chinese Plain. Environ. Pollut. 156 (3), 651-656.

Lu, W., Yang, L., Chen, J., Wang, X., Li, H., Zhu, Y., Wen, L., Xu, C., Zhang, J., Zhu, T., Wang, W., 2016. Identification of concentrations and sources of PM2.5-bound PAHs in North China during haze episodes in 2013. Air Qual. Atmos. Health 9 (7), 823-833.

Lui, K.H., Bandowe, B.A.M., Tian, L., Chan, C.-S., Cao, J.-J., Ning, Z., Lee, S.C., Ho, K.F., 2017. Cancer risk from polycyclic aromatic compounds in fine particulate matter generated from household coal combustion in Xuanwei, China. Chemosphere 169, 660-668. 
Madureira, J., Paciência, I., Rufo, J., Severo, M., Ramos, E., Barros, H., de Oliveira Fernandes, E 2016. Source apportionment of CO2, PM10 and VOCs levels and health risk assessment in naturally ventilated primary schools in Porto, Portugal. Build. Environ. 96, 198-205.

Manoli, E., Kouras, A., Samara, C., 2004. Profile analysis of ambient and source emitted particle-bound polycyclic aromatic hydrocarbons from three sites in northern Greece. Chemosphere 56, 867-878

Melymuk, L., Robson, M., Helm, P.A., Diamon, M.L., 2012. PCBs, PBDEs, and PAHs in Toronto air: spatial and seasonal trends and implications for contaminant transport. Sci. Total Environ. 429, 272-280.

Miranda, A.I., Martins, V., Cascão, P., Amorim, J.H., Valente, J., Tavares, R., Tchepel, O., Borrego, C., Cordeiro, C.R., Ferreira, A.J., Viegas, D.X., Ribeiro, L.M., Pita, L.P., 2010. Monitoring of firefighters exposure to smoke during fire experiments in Portugal. Environ. Int. 36, 736-745

Mirante, F., Alves, C., Pio, C., Pindado, O., Perez, R., Revuelta, M.A., Artiñano, B., 2013. Organic composition of size segregated atmospheric particulate matter, during summe and winter sampling campaigns at representative sites in Madrid, Spain. Atmos. Res. $132-133,345-361$.

Montaño-Soto, T., Garza-Ocañas, L., Badillo-Castañeda, C., Garza-Ulloa, H., 2017. Determination of polycyclic aromatic hydrocarbons in ambient particulate matter PM2.5 and 1-hydroxypyrene in children from an area near an oil refinery in Northeast Mexico. Hum. Ecol. Risk. Assess. 23 (1), 125-140.

Oda, J., Nomura, S., Yasuhara, A., Shibamoto, T., 2001. Mobile sources of atmospheric polycyclic aromatic hydrocarbons in a roadway tunnel. Atmos. Environ. 35, 4819-4827.

Okona-Mensah, K.W., Battershill, J., Boobis, A., Fielder, R., 2005. An approach to investigating the importance of high potency polycyclic aromatic hydrocarbons (PAHs) in the induction of lung cancer by air pollution. Food Chem. Toxicol. 43, 1103-1116.

Oliveira, M., Slezakova, K., Delerue-Matos, C., Pereira, M.C., Morais, S., 2016a. Assessment of air quality in preschool environments (3-5 years old children) with emphasis on elemental composition of PM10 and PM2.5. Environ. Pollut. 214, 430-439.

Oliveira, M., Slezakova, K., Delerue-Matos, C., Pereira, M.C., Morais, S., 2016b. Assessment of polycyclic aromatic hydrocarbons in indoor and outdoor air of preschool environments (3-5 years old children). Environ. Pollut. 208, 382-394.

Oliveira, M., Slezakova, K., Delerue-Matos, C., Pereira, M.C., Morais, S., 2015a. Polycyclic aromatic hydrocarbon emissions from forest fires: assessment of firefighters' exposure. In: Boone, C. (Ed.), Polycyclic Aromatic Hydrocarbons, Series: Environmental Science. Engineering and Technology. Nova Science Publishers, Hauppauge, New York, pp. 59-94.

Oliveira, M., Slezakova, K., Delerue-Matos, C., Pereira, M.C., Morais, S., 2015b. Polycyclic aromatic hydrocarbons: levels and phase distributions in preschool microenvironment. Indoor Air 25 (5), 557-568.

Perwak, J., Byrne, M., Coons, S., Goyer, M., Harris, J., Cruse, P., DeRosier, R., Moss, K., Wendt S., 1982. An exposure and risk assessment for benzo[u]pyrene and other polycyclic aromatic hydrocarbons. Benzo[a]pyrene, Acenaphthylene, Benz[a]anthracene, Benzo[b]fluoranthene, Benzo[k]fluroanthene, Benzo[g,h,i]perylene, Chrysene, Dibenz[a,h]anthracene, and Indeno[1,2,3-c,a]pyrene. Volume 4. US Environmental Protection Agency, Office of Water Regulations and Standards, Washington, D.C.

Pleil, J.D., Stiegel, M.A., Fent, K.W., 2014. Exploratory breath analysis for assessing toxic dermal exposures of firefighters during suppression of structural burns. J. Breath Res. 8, 037107.

Pio, C.A., Alves, C.A., Duarte, A.C. 2001. Identification, abundance and origin of atmospheric organic particulate matter in a Portuguese rural area. Atmos. Environ. 35 $1365-1375$

Poirier, M.C., 2004. Chemical-induced DNA damage and human cancer risk. Nat. Rev. Cancer 4, 630-637.

Pratt, M.M., John, K., MacLean, A.B., Afework, S., Phillips, D.H., Poirier, M.C., 2011. Polycyclic aromatic hydrocarbon (PAH) exposure and DNA adduct semi-quantitation in archived human tissues. Int. J. Environ. Res. Public Health 8 (7), 2675-2691.

Qi, H., Li, W.-L., Zhu, N.-Z., Ma, W.-L., Liu, L.-Y., Zhang, F., Li, Y.-F., 2014. Concentrations and sources of polycyclic aromatic hydrocarbons in indoor dust in China. Sci. Total Environ. 491-492, 100-107.

Ravindra, K., László Bencs, L., Wauters, E., de Hoog, J., Felix Deutsch, F., Edward, Roekens E., Bleux, N., Berghmans, P., Van Grieken, R., 2006. Seasonal and site-specific variation in vapour and aerosol phase PAHs over Flanders (Belgium) and their relation with anthropogenic activities. Atmos. Environ. 40 (4), 771-785.

Ravindra, K., Sokhi, R., Grieken, R.V., 2008. Atmospheric polycyclic aromatic hydrocarbons: source attribution, emission factors and regulation. Atmos. Environ. 42, 2895-2921.

Reinhardt, T.E., Ottmar, R.D., 2004. Baseline measurements of smoke exposure among wildland firefighters. J. Occup. Environ. Hyg. 1, 593-606.

Reisen, F., Brown, S.K., 2009. Australian firefighters' exposure to air toxics during bushfire burns of autumn 2005 and 2006. Environ. Int. 35, 342-352.

Reisen, F., Brown, S., Cheng, M., 2006. Air toxics in bushfire smoke: firefighter's exposure during prescribed burns. Forest Ecol. Manag. 234, S144.

Rengarajan, T., Rajendran, P., Nandakumar, N., Lokeshkumar, B., Rajendran, P., Ikuo Nishigaki, I., 2015. Exposure to polycyclic aromatic hydrocarbons with special focus on cancer. Asian Pac. J. Trop. Biomed. 5 (3), 182-189.

Robinson, M.S., Anthony, T.R., Littau, S.R., Herckes, P., Nelson, X., Poplin, G.S., Burgess, J.L., 2008. Occupational PAH exposures during prescribed pile burns. Ann. Occup. Hyg. 52 497-508

Rogge, W.F., Hildemann, L.M., Mazurek, M.A., Cass, G.R., Simoneit, B.R.T., 1993a. Sources of fine organic aerosol. 2. Noncatalyst and catalystequipped automobiles and heavyduty diesel trucks. Environ. Sci. Technol. 27, 636-651.

Rogge, W.F., Hildemann, L.M., Mazurek, M.A., Cass, G.R., Simoneit, B.R.T., 1993b. Sources of fine organic aerosol. 3. Road dust, tire debris and organometallic brake lining dust: roads as sources and sinks. Environ. Sci. Technol. 27, 1892-1904.

Rota, M., Bosetti, C., Boccia, S., Boffetta, P., La Vecchia, C., 2014. Occupational exposures to polycyclic aromatic hydrocarbons and respiratory and urinary tract cancers: an updated systematic review and a meta-analysis to 2014. Arch. Toxicol. 88 (8), $1479-1490$

Shen, G., Wei, S., Zhang, Y., Wang, R., Wang, B., Li, W., Shen, H., Huang, Y., Chen, Y., Chen, H., Wei, W., Tao, S., 2012. Emission of oxygenated polycyclic aromatic hydrocarbons from biomass pellet burning in a modern burner for cooking in China. Atmos. Environ. 60, 234-237.

Shen, B., Whitehead, T.P., McNeel, S., Brown, F.R., Dhaliwal, J., Das, R., Israel, L., Park, J.-S., Petreas, M., 2015. High levels of polybrominated diphenyl ethers in vacuum cleaner dust from California fire stations. Environ. Sci. Technol. 49, 4988-4994.

Sicre, M.A., Marty, J.C., Saliot, A., Aparicio, X., Grimalt, J., Albaiges, S., 1987. Aliphatic and aromatic hydrocarbons in different sized aerosols over the Mediterranean Sea: occurrence and origin. Atmos. Environ. 21, 2247-2259.

Simcik, M.F., Eisenreich, S.J., Lioy, P.J., 1999. Source apportionment and source/sink relationships of PAHs in the coastal atmosphere of Chicago and Lake Michigan. Atmos. Environ. 33, 5071-5079.

Slezakova, K., Castro, D., Begonha, A., Delerue-Matos, C., Alvim-Ferraz, M.C., Morais, S., Pereira, M.C., 2011. Air pollution from traffic emissions in Oporto, Portugal: health and environmental implications. Microchem. J. 99, 51-59.

Slezakova, K., Castro, D., Delerue-Matos, C., Alvim-Ferraz, M.C.M., Morais, S., Pereira, M.C. 2013a. Impact of vehicular traffic emissions on particulate-bound PAHs: levels and associated health risks. Atmos. Res. 127, 141-147.

Slezakova, K., Castro, D., Pereira, M.C., Morais, S., Delerue-Matos, C., Alvim-Ferraz, M.C., 2010. Influence of traffic emissions on the carcinogenic polycyclic aromatic hydrocarbons in outdoor breathable particles. J. Air Waste Manage. Assoc. 60, 393-401.

Slezakova, K., Castro, D., Delerue-Matos, C., Morais, S., Pereira, M.C., 2014. Levels and risks of particulate-bound PAHs in indoor air influenced by tobacco smoke: a field measurement. Environ. Sci. Pollut. R. 21, 4492-4501.

Slezakova, K., Pires, J.C.M., Castro, D., Alvim-Ferraz, M.C.M., Delerue-Matos, C., Morais, S., Pereira, M.C., 2013b. PAH air pollution at a Portuguese urban area: carcinogenic risks and sources identification. Environ. Sci. Pollut. R. 20 (6), 3932-3945.

Soteriades, E.S., Smith, D.L., Tsismenakis, A.J., Baur, D.M., Kales, S.N., 2011. Cardiovascular disease in US firefighters-a systematic review. Cardiol. Rev. 19, 202-215.

Tarantini, A., Maitre, A., Lefebvre, E., Marques, M., Rajhi, A., Douki, T., 2011. Polycyclic aromatic hydrocarbons in binary mixtures modulate the efficiency of benzo[a]pyrene to form DNA adducts in human cells. Toxicology 279, 36-44.

Teixeira, E. Mattiuzi, C. Agudelo-Castañeda, D., de Oliveira Garcia, K., Wiegand, F, 2013. Polycyclic aromatic hydrocarbons study in atmospheric fine and coarse particles using diagnostic ratios and receptor model in urban/industrial region. Environ. Monit. Assess. 185, 9587-9602.

Tobiszewski, M., Namieśnik, J., 2012. PAH diagnostic ratios for the identification of pollution emission sources. Environ. Pollut. 162, 110-119.

Tuntawiroon, J., Mahidol, C., Navasumrit, P., Autrup, H., Ruchirawat, M., 2007. Increased health risk in Bangkok children exposed to polycyclic aromatic hydrocarbons from traffic-related sources. Carcinogenesis 28, 816-822.

Usenko, S.L., Massey Simonich, K.J., Haggeman, J.E., Schrlau, L., Geiser, L., Campbell, D.H., Appleby, P.G., Landers, D.H., 2010. Sources and deposition of polycyclic aromatic hydrocarbons to western U.S. National Parks. Environ. Sci. Technol. 44, 4512-4518.

U.S. Environmental Protection Agency (USEPA), 1989. Risk Assessment Guidance for Superfund, Vol. I: Human Health Evaluation Manual, EPA/540/1-89/002. Office of Emergency and Remedial Response, Washington, DC

U.S. Environmental Protection Agency (USEPA), 1990. Compendium of methods for the determination of air pollutants in indoor air. Atmospheric Research and Exposure Assessment Laboratory. Research Triangle Park, NC.

U.S. Environmental Protection Agency (USEPA), 2014. Priority pollutant list. Code of Federal Regulations: 40 CFR Part 423, Appendix A Available from. https://www.epa.gov/ sites/production/files/2015-09/documents/priority-pollutant-list-epa.pdf.

U.S. Environmental Protection Agency (USEPA), 2016. Risk-Based Concentration Table. (retrieved from.<http://www.epa.gov/reg3hwmd/risk/human/rb-concentration table/usersguide.htm>, accessed in June 2016).

World Health Organization (WHO), 1987. Air Quality Guidelines for Europe. WHO Regional Office for Europe, Copenhagen, Denmark.

World Health Organization (WHO), 2000. Air Quality Guidelines for Europe. second ed. WHO Regional Office for Europe, Copenhagen, Denmark.

World Health Organization (WHO), 2010. WHO Guidelines for Indoor Air Quality: Selected Pollutants. Regional Office for Europe of the World Health Organization, Copenhagen, Denmark.

World Health Organization (WHO), 2013. State of the Science of Endocrine Disrupting Chemicals 2012. United Nations Environment Programme and the World Health Organization, Geneva

World Health Organization, 2016. World health survey B - individual questionnaire 2002. World Health Organization Evidence and Information Policy (accessed in June 2016, available from: http://www.who.int/healthinfo/survey/whslongindividuala.pdf).

Yunker, M.B., Macdonald, R.W., Vingarzan, R., Mitchell, R.H., Goyette, D., Sylvestre, S., 2002. PAHs in the Fraser River basin: a critical appraisal of PAH ratios as indicators of PAH source and composition. Org. Geochem. 33, 489-515.

Zencak, Z., Klanova, J., Holoubek, I., Gustafsson, Ö., 2007. Source apportionment of atmospheric PAHs in theWestern Balkans by natural abundance radiocarbon analysis. Environ. Sci. Technol. 41, 3850-3855.

Zhang, W., Zhang, S., Wan, C., Yue, D., Ye, Y., Wang, X., 2008. Source diagnostics of polycyclic aromatic hydrocarbons in urban road runoff, dust, rain and canopy through fall. Environ. Pollut. 153, 594-601.

Ziech, D., Franco, R., Pappa, A., Panayiotidis, M.I., 2011. Reactive oxygen species (ROS)-induced genetic and epigenetic alterations in human carcinogenesis. Mutat. Res. 711 (1), 167-173. 